\title{
IZVRŠNA TIJELA U LOKALNOJ SAMOUPRAVI - KOMPARATIVNI PRIMJERI I HRVATSKO ISKUSTVO
}

Sažetak: $\quad$ Predmet ovog rada ovlasti su izvršnih tijela u jedinicama lokalne samouprave, kao i njihov međuodnos prema predstavničkim tijelima, posebice u svjetlu međusobnog utjecaja na lokalne političke procese. Zbog toga se koristi komparativna metoda analize izbora i funkcioniranja izvršnih tijela u jedinicama lokalne samouprave u Hrvatskoj, u odnosu na praksu u Njemačkoj lokalnoj samoupravi te u lokalnim samoupravama odabranih kontinentalno-europskih zemalja. Kao dopuna komparativnoj metodi, koristi se metoda analize i sinteze. Metodom analize raščlanjuje se postojeća političko-upravna praksa u analiziranim sustavima lokalne samouprave. Na temelju provedene analize metodom sinteze postavljaju se načelno dva modela izvršnih tijela: monokratskog i kolegijalnog. Očekivani znanstveni doprinos ovog rada bolje je razumijevanje funkcioniranja izvršnih tijela u lokalnoj samoupravi, kao i dinamike odnosa u trokutu građani, predstavnička tijela i izvršna tijela na lokalnoj razini.

Ključne riječi: $\quad$ lokalna samouprava, političke i upravne institucije, izvršna tijela, tipovi izvršnih tijela

\section{UVOD}

Jedno od najvažnijih pitanja koje se postavlja u procesu provođenja političkih odluka pitanje je na koji način se osigurava njihova implementacija od trenutka kada one budu donesene od strane politički odlučujućih tijela, do trenutka njihove primjene na adresate na koje se odnose. Ovo pitanje otvara se kako kod političkih i upravnih institucija na središnjoj državnoj razini, tako i kod institucija koje djeluju na razini jedinica lokalne samouprave. Pitanje mogućnosti provedbe različitih političkih odluka ovisi o čitavom nizu faktora. Mogu se tako izdvojiti stupanj centralizacije, odnosno decentralizacije države i njezinih institucija. Važan je također

\footnotetext{
* Dr. sc. Mirko Klarić, izvanredni profesor na Katedri za upravnu znanost Pravnog fakulteta Sveučilišta u Splitu. Domovinskog rata 8, 21000 Split, Republika Hrvatska. Adresa e-pošte: klaricmirko@gmail.com. ORCID: http://orcid.org/0000-0002-07922978.
} 
i fiskalni i upravni kapacitet javnih tijela, kako na centralnoj, tako i na lokalnoj razini, koji uključuje i sposobnost provođenja pojedinih političkih odluka, kao i odnos između središnjih i lokalnih tijela i njihova međusobna podjela nadležnosti. Poseban faktor predstavlja primjena pojedinih načela u procesu javnog upravljanja, kao što je primjerice načelo supsidijarnosti, koji daje prioritet tijelima koja djeluju na nižoj, lokalnoj razini i sl.

Neovisno o tome koja se sve rješenja primjenjuju u praksi, očekuje se da se politički i upravni sustavi ustrojavaju na način da osiguraju efikasnu i efektivnu provedbu političkih odluka, koje se donose u politički odlučujućim tijelima, te da osiguraju dostupnost različitih javnih usluga u društvenoj zajednici. Dio javnih usluga, osobito onih koje su od lokalnog interesa, ostvaruje se preko tijela jedinica lokalne samouprave. Koji je to dio usluga u odnosu na ostatak sustava javne uprave, ovisi o upravno-političkom ustrojstvu svake države, kao i razdiobi ovlasti između centralnih i lokalnih institucija. ${ }^{1}$ Efikasnost lokalnih institucija ovisi o modelu koji se implementira pri organizaciji lokalne samouprave. U svemu tome važnu ulogu imaju izvršna tijela u okviru lokalne samouprave. Ovdje naravno postoje različiti pristupi kod određivanja strukture i međuodnosa lokalnih tijela u okviru jedinica lokalne samouprave. U tom smislu, više je autora analiziralo različite organizacijske modele lokalne samouprave, u kojima pojedina tijela imaju više ili manje izraženu ulogu. Dio hrvatskih autora već je posebno analizirao položaj i ulogu izvršnih tijela u jedinicama lokalne samouprave. Ovdje se polazi načelno od triju modela organizacije izvršnih tijela: monokratskog tipa lokalnih izvršnih funkcija, kolegijalnog tipa lokalnih izvršnih funkcija te pluralnog tipa lokalnih izvršnih funkcija. ${ }^{2}$ Navedena tipologija obuhvaća različite organizacijske oblike, u okviru kojih se osigurava djelovanje izvršnih institucija u lokalnoj samoupravi. Ovaj rad polazi od postojećih znanstvenih i stručnih analiza položaja i uloge izvršnih tijela u jedinicama lokalne samouprave, uvažavajući načelno podjelu izvršnih tijela na monokratske, kolegijalne i pluralne. Držeći se prije uspostavljenog kategorijalnog aparata, u ovom radu posebno će se analizirati struktura izvršnih tijela u jedinicama lokalne samouprave u zemljama njemačkoga govornog područja, kao i onima koje su se razvijale pod njihovim utjecajem te položaj i uloga izvršnih tijela jedinica lokalne samouprave ${ }^{3}$ u Republici Hrvatskoj, posebice u svjetlu izmjena koje su dovele do uspostave monokratskog tipa lokalnih izvršnih funkcija.

S obzirom na to da su zemlje njemačkoga govornog područja, posebice Austrija, povijesno i tradicijski izvršile snažan utjecaj na razvoj upravnih institucija i upravne kulture u Hrvatskoj, na temelju provedene analize žele se izdvojiti pozitivna iskustva u ustrojstvu i funkcioniranju lokalne samouprave, koja bi mogla poslužiti kao svojevrstan putokaz u razvoju lokalnih in-

$1 \quad$ Postoji više različitih modela koji definiraju organizacijsko ustrojstvo jedinica lokalne samouprave pri pružanju javnih usluga od lokalnog karaktera. Pavić tako analizira različite modele organizacije komunalnih servisa u suvremenim gradovima, polazeći od karakterističnih problema koji su tipični za lokalne javne službe, pa sve do problema pružanja javnih servisa u velikim megalopolisima, u kojima je, upravo zbog njihove veličine, posebno izazovno osiguravanje različitih javnih potreba od neposrednog interesa za njihove građane. U tom smislu Pavić analizira različite organizacijske alate koji se koriste $u$ prevladavanju upravnih problema metropolitanizacije, poput primjerice, urbanizacije okruga, dobrovoljnih metropolitanskih vijeća, spajanja grada i okruga, metropolitanske federacije, aneksije ili pripajanja okolnog područja gradu i sl. O tome više u: Pavić, Ž., Od antičkog do globalnog grada, Pravni fakultet u Zagrebu, Zagreb, 1999.

2 Ovdje se posebno može izdvojiti značajan doprinos S. Ivaniševića navedenoj problematici. U jednom od novije publiciranih radova Ivanišević iznosi tipologiju strukturnih oblika i komparativni pregled izvršnih institucija u lokalnoj samoupravi.

3 Ovdje se pojam "jedinice lokalne samouprave” koristi ne samo za općine i gradove u Hrvatskoj, nego i za županije jer same županije, unatoč nazivlju i terminologiji koja se koristi u Ustavu Republike Hrvatske i Zakonu o lokalnoj i područnoj (regionalnoj) samoupravi, prema svojoj pravnoj i upravnoj prirodi, ne predstavljaju regije u punom značenju te riječi, nego prije jedinice lokalne samouprave u drugom stupnju. 
stitucija u Republici Hrvatskoj. Zbog toga će se u radu koristiti nekoliko znanstvenih metoda istraživanja: metoda komparativne analize njemačke lokalne samouprave i lokalne samouprave odabranih zemalja, u odnosu na lokalnu samoupravu u Republici Hrvatskoj. Na temelju provedene komparativne analize primijenit će se metoda sinteze, kojom će se na temelju proučenog faktičkog stanja pristupiti tipologiji i oblikovanju modela izvršnih tijela u lokalnoj samoupravi. Očekivani znanstveni doprinos bit će bolje razumijevanje položaja izvršnih tijela u okviru sustava lokalne samouprave, kao i dinamike odnosa koja postoji na relaciji građani, predstavnička tijela i izvršna tijela u jedinici lokalne samouprave, kroz razvoj osnovnih modela izvršnih tijela.

\section{POVIJESNI OKVIR}

Republika Hrvatska, do donošenja Zakona o lokalnoj samoupravi i upravi iz 1992. godine, imala je posve drugo organizacijsko ustrojstvo teritorija. Njezin je teritorij bio podijeljen na općine, čiji je broj varirao između 102 i 114, i zajednice općina, kao lokalnih jedinica na regionalnoj razini, kojih je bilo ukupno devet. ${ }^{4}$ Ovakvo upravno-teritorijalno ustrojstvo zemlje, iako organizirano na tadašnjem tzv. komunalnom sistemu, koji je polazio od ideološke matrice "marksističke komune", u praksi je dovodio do decentralizacije obavljanja čitavog niza upravnih djelatnosti. Upravo su tako koncipirane općine imale snažan fiskalni i upravni kapacitet, koji im je omogućavao obavljanje različitih komunalnih, upravnih, urbanističko-infrastrukturno-građevinskih, društvenih i inspekcijskih djelatnosti. ${ }^{5}$ Zahvaljujući općoj klauzuli u korist lokalnih poslova, prema kojoj sve ono što nije bilo u izričitoj nadležnosti republičkih i federalnih tijela, bilo je u nadležnosti lokalnih tijela, općine su uživale iznimno visok stupanj autonomije i samostalnosti. ${ }^{6}$ Ovaj se model uspostavom demokratskih političkih struktura od izbora održanih 1990. godine mijenja, dijelom iz funkcionalnih, a dijelom iz političkih razloga. ${ }^{7}$ Iako nije sporno da se postojeći sustav lokalne samouprave trebao organizacijski i funkcionalno prilagoditi novonastalim društvenim i političkim prilikama u hrvatskom društvu, mnogi hrvatski upravni stručnjaci skloni su istaknuti kako je novouspostavljeni model lokalne samouprave predstavljao potpunu suprotnost dotadašnjem sustavu. Broj jedinica lokalne samouprave tom je reformom upeterostručen, u odnosu na dotadašnji broj općina. Uz to, sustav je utemeljen na velikom broju relativno malih općina te formalnom razlikovanju između seoskih lokalnih

4 Nakon donošenja Ustava iz 1974. u SR Hrvatskoj osnovano je devet zajednica općina (Rijeka, Zagreb, Split, Osijek, Sisak, Varaždin, Karlovac, Bjelovar i Gospić). Općine užeg gradskog područja Zagreba osnovale su gradsku zajednicu općina, koja je 1990. godine spojena u općinu pod nazivom Grad Zagreb. Usp. Blažević, R., Upravna znanost, Društveno veleučilište u Zagrebu, Zagreb, 2010., str. 351.

5 O komunalnom sustavu u Hrvatskoj vidi pobliže u Tomac, Z., Novi komunalni sistem, RANS “Moša Pijade - Porodica i domaćinstvo", Zagreb, 1990.

6 Ovdje ipak valja istaknuti ogradu kako je bila riječ o jednopartijskom političkom sustavu koji je funkcionirao prema modelu "partije i države", pa su upravno-politička tijela i institucije snažno ovisile o stajalištima i shvaćanjima partijskih tijela, koja su na taj način ograničavala političku autonomiju i unificirala politički sustav. O tome više u Pusić, E., i dr., Hrvatska središnja državna uprava i usporedni upravni sustavi, Školska knjiga, Zagreb, 1997., str. 70.-71.

7 Kao funkcionalni razlog navodi se okolnost da je postojeći model previše naslonjen na marksističku doktrinu komune ta kao takav nije prikladan za uspostavu učinkovitog upravnog aparata, dok je temeljni politički razlog pitanje izgradnje demokratskih političkih institucija, koje ć s jedne strane polaziti od poštovanja volje većine, a s druge strane razvijati učinkovite mehanizme zaštite prava manjine. 
jedinice (općine), urbanih lokalnih jedinica (gradovi). Općine su formirane na pretežno seoskom području i trenutačno ih ima 429, a za urbanizirana područja predviđeno je formiranje gradova, kojih danas ima $127 .{ }^{8} \mathrm{Na}$ regionalnoj razini predviđene su županije. Broj županija je ostao stabilan i ima ih ukupno 21 (dvadeset županija plus Grad Zagreb).

Iako podijeljena na veliki broj jedinica lokalne samouprave, Hrvatska se našla u pomalo paradoksalnoj situaciji da je kao zemlja ovom reformom visoko centralizirana, dok su ovlasti jedinica lokalne samouprave znatno sužene. Zbog toga je bilo više kritičkih promišljanja vezanih uz ovakvo ustrojstvo zemlje, gdje su brojni stručnjaci ukazivali na potrebu veće decentralizacije i jačanja upravnih i fiskalnih kapaciteta lokalne samouprave. Kako se prijašnji sustav lokalne samouprave razvijao dosta dugo i postupno i kako se sastojao od manjeg broja većih općina te zajednica općina čiji je broj bio više nego dvostruko manji od sadašnjeg broja županija, brojni su autori upozoravali kako novi model može imati brojne manjkavosti i loša rješenja. ${ }^{9}$ Ovdje valja napomenuti kako je novim ustrojstvom lokalne samouprave uspostavljen "kolegijalni tip lokalnih izvršnih institucija", ${ }^{10}$ prema kojem dolazi do uspostave lokalnih poglavarstava, slično modelu koji prevladava u Austriji. ${ }^{11}$ Ovaj model prisutan je sve do 2009. godine, kada dolazi do izmjene izbornog sustava i neposrednog izbora načelnika, gradonačelnika i župana. Neposredan izbor općinskog načelnika, gradonačelnika i župana otvara novo polje u odnosima unutar općinskih struktura pa se težište s kolektivnog odlučivanja prebacuje i koncentrira u rukama pojedinaca koji legitimitet za donošenje samostalnih političkih odluka dobivaju na lokalnim izborima koji se sve više personaliziraju.

Promjenama Ustava iz 2000. godine počinje proces decentralizacije i jačanje kapaciteta jedinica lokalne samouprave. Novim se rješenjima razdvajaju poslovi državne uprave od poslova lokalne samouprave koja postaje samostalna i potpuno autonomna u odnosu na državnu vlast, s vlastitim, zakonski definiranim ovlastima. Iako nije došlo do promjene upravno-teritorijalnog ustrojstva zemlje, dolazi do povećanja ovlasti jedinica lokalne samouprave i širenja fiskalnih kapaciteta. Institucija župana također se preoblikovala jer župan prestaje biti i čelnik državne uprave u županiji, a županijski uredi prestaju obuhvaćati poslove državne uprave. Umjesto toga, osnivaju se uredi državne uprave u županijama, koji su hijerarhijski podređeni tijelu koje je nadležno za poslove državne uprave. Županije postaju jedinice (područne) regionalne samouprave. Ustav uvodi opću klauzulu u određivanju lokalnih poslova te prihvaća načelo supsidijarnosti i solidarnosti. Zakon o lokalnoj i područnoj (regionalnoj) samoupravi iz 2000.

$8 \quad$ Usp. isto, str. 352.

9 O tome više u Koprić, I., Uloga županija u hrvatskom sustavu lokalne samouprave i uprave 1990-ih godina, i perspektive regionalizacije nakon promjene Ustava iz 2000-te godine, Hrvatska javna uprava, vol. 3, br. 1, 2001., str. 63.-87.; Koprić, I., Državna uprava $i$ lokalna samouprava u Hrvatskoj 1990.-2001. - vladavina prava ili politike?, Zbornik Pravnog fakulteta u Zagrebu, Zagreb, vol. 51, br. 6, 2001., str.1275.-1295.; Pusić, E., Lokalna samouprava u Hrvatskoj, Hrvatska javna uprava, vol. 2, br. 2, 2000., str. 347.-349.; Ivanišević, S., Teritorijalna osnova lokalne i regionalne samouprave, u: Stručne osnove za reformu lokalne samouprave u Hrvatskoj, Hrvatski pravni centar, Projekt “Zakonski okvir decentralizacije u Hrvatskoj”, Zagreb, 2000.

Usp. Ivanišević, S., nav. djelo, 58.-97.

Ivanišević daje prikaz organizacijske strukture u jedinicama lokalne samouprave u Austriji, prema kojoj u jedinicama lokalne samouprave postoji predstavničko tijelo, iz kojeg se u pravilu biraju članovi poglavarstva i općinski načelnik, odnosno gradonačelnik. Općinski načelnik, odnosno gradonačelnik obnašaju izvršnu vlast u jedinicama lokalne samouprave, dok predstavnička tijela usvajaju opće akte kojima reguliraju svakodnevni život u lokalnoj zajednici, a na izvršnim tijelima je implementacija tih odluka. Ovdje važnu ulogu ima međuodnos između općinskog vijeća i općinskog poglavarstva jer sudbina općinskog poglavarstva te općinskog načelnika i gradonačelnika ovisi o postojanju potpore od strane općinskih vijećnika. Usp. i Wastl-Walter, D., Gemeiden in Österreich. Im Spannungsfeld von staatlichen System und lokaler Lebenswelt, Böhlau Verlag, Wien, Koln, Graz, 2000. 
godine $^{12}$ bio je znatno kraći u određivanju lokalnih poslova, premda je sadržavao opću klauzulu, da bi poslije specijalni zakoni doneseni nakon toga znatno suzili listu poslova iz samoupravnog djelokruga u odnosu na ustavne garancije djelokruga jedinica lokalne samouprave. ${ }^{13}$

\section{MODELI IZBORA NAČELNIKA, GRADONAČELNIKA I ŽUPANA}

Jedna od značajnijih novina koje se uvode u hrvatski sustav lokalne samouprave neposredni je izbor načelnika, gradonačelnika i župana, kao čelnika jedinica lokalne samouprave, koji ujedno predstavlja neposredno izabranog nositelja izvršne vlasti i ujedno lokalnog poglavara. Ovaj sustav nije nepoznanica u svijetu, i kao takav postoji u čitavom nizu zemalja. ${ }^{14}$ Ovaj se sustav uvodi Zakonom o izmjenama i dopunama Zakona o lokalnoj i područnoj (regionalnoj) samoupravi. ${ }^{15}$ Dotad je sustav bio ustrojen prema modelu neizravnog izbora načelnika, gradonačelnika i župana kojeg je biralo gradsko i općinsko vijeće te županijska skupština.

Valja napomenuti kako postoji više različitih načina odabira izvršnih dužnosnika. Prvi način je da ih bira lokalno predstavničko tijelo, neizravno i u pravilu iz reda svojih članova. Drugi način je da ih lokalno predstavničko tijelo imenuje na temelju dokazane stručnosti i sposobnosti, a oni izvršne poslove obavljaju profesionalno. ${ }^{16}$ Treći način je neposredan izbor izvršnih dužnosnika od strane građana. ${ }^{17}$ Neposredan izbor lokalnih izvršnih tijela dovodi do izjednačenosti njihova političkog legitimiteta s lokalnim predstavničkim tijelom pa su lokalna izvršna tijela za svoj rad odgovorna biračima koji su ih izabrali, a ne lokalnom predstavničkom tijelu. Kako bi se uredila njihova odgovornost za vrijeme trajanja mandata, potrebno je urediti institut opoziva ili pak uvesti mogućnost nekom državnom tijelu da ih može smijeniti, na temelju dokazane optužbe za zlouporabu vlasti. Četvrti način odabira je onaj u kojem ih imenuje ili odlučujuće sudjeluje u njihovu imenovanju neko više tijelo, uključujući središnju vladu i državnog poglavara. ${ }^{18}$ Ovdje valja napomenuti kako je ovaj način odabira najmanje demokratski

12 Narodne novine, broj 33/2001, 60/2001 - vjerodostojno tumačenje, 129/2005, 109/2007, 125/2008, 36/2009.

13 O tome više u: Koprić, I., Stanje lokalne samouprave u Hrvatskoj, Hrvatska javna uprava, vol. 10, br. 3, 2010., str. 667.

14 U literaturi se tako navodi kako se ovaj sustav uvodi prema uzoru na načelničko uređenje u gradovima u Sjedinjenim Američkim Državama, a karakterističan je i za druge države, koje su dalje razvijale ovaj model upravljanja prema uzoru na SAD. U tom smislu navode se primjeri Kanade, zemalja Srednje i Južne Amerike, a od azijskih zemalja izdvaja se Japan. U Europi se navodi primjer Njemačke, osobito njezinih južnih pokrajina. O tome više u: Ivanišević, S., nav. djelo, str. 48. i dalje. S druge pak stane Koprić navodi kako se praksa neposrednog izbora načelnika, gradonačelnika i župana znatno proširila kako u Njemačkoj, tako i u drugim europskim zemljama, kao što su Italija, Slovenija, Irska, a predmet je eksperimentiranja i u Norveškoj, Velikoj Britaniji, uvodi se i u dijelovima Austrije i dr. O tome vidi pobliže u: Koprić, I., Neposredni izbor gradonačelnika i općinskog načelnika, u: Koprić, I. (ur.): Javna uprava. Nastavni materijali, Društveno veleučilište u Zagrebu i Pravni fakultet u Zagrebu, Zagreb, 2006., str. 322.

Narodne novine, broj 109/2007, 125/2008, 36/2009.

16 Kao, primjerice, u SAD-u, tzv. model city manager.

17 I kod prvog i kod drugog načina odabira zajedničko je to da su lokalni izvršni dužnosnici ili članovi izvršnog kolegija podređeni lokalnom predstavničkom tijelu, te da mu odgovaraju za svoj rad. Ako je riječ o izboru utemeljenom na primarno političkim kriterijima, ta se odgovornost regulira kroz mehanizam izglasavanja nepovjerenja. Ako je riječ o imenovanju na temelju stručnosti i sposobnosti, lokalno predstavničko tijelo koje je nezadovoljno radom izvršnog dužnosnika, može ga smijeniti s položaja, odnosno s njime raskinuti ugovor. Usp. Ivanišević, S., str. 14.-15.

18 Uglavnom je riječ o sudjelovanju u imenovanju glavnog izvršnog dužnosnika te eventualno njegovih zamjenika, dok ostale bira lokalno predstavničko tijelo. O tome više u: Ivanišević, S., nav. djelo, str. 15.-16. 
te limitira mogućnost utjecaja građana u lokalnoj zajednici na vođenje lokalnih javnih politika, jednostavno zbog okolnosti da ne mogu utjecati na izbor čelnika izvršnih tijela koji kreiraju javne politike u lokalnoj zajednici.

Neki od razloga koji su se navodili u hrvatskoj javnosti vezano za uvođenje neposrednog izbora načelnika, gradonačelnika i župana bili su: smanjenje političke trgovine među strankama i nezavisnim listama, poštovanje volje građana glede izbora lokalnih čelnika, napredak u funkcioniranju jedinica lokalne samouprave jer su neposrednim izborom i redizajnom same institucije načelnika, gradonačelnika i župana ojačane njihove ovlasti te tako povećana politička odgovornost prema građanima.

Pa ipak, u literaturi se može naći podatak kako neposredni izbor gradonačelnika nije u Europi onoliko rasprostranjen kao što se to katkad pokušava prikazati, ali je prisutan u mjeri u kojoj se ne može zanemariti.

Analiza odnosa koji postoje između gradonačelnika kao nositelja izvršne vlasti, i predstavničkog tijela, kao kreatora lokalnih javnih politika i sukreatora u donošenju političkih odluka u nekim europskim zemljama, pokazuje različita iskustva, ovisno o tome je li težište odlučivanja i autoritet u donošenju političkih odluka više na strani gradonačelnika ili pak predstavničkog tijela u jedinici lokalne samouprave. ${ }^{19}$

Ipak, za potrebe ovog rada težište analize bit će na Njemačkoj i na zemljama njemačkog govornog područja. Ovaj se pristup nameće zbog nekoliko razloga, kao što su: raznolikost u institucionalnom uređenju odnosa između predstavničkih i izvršnih tijela u jedinicama lokalne samouprave, već naglašena tendencija k postupnom jačanju onih organizacijskih modela u lokalnoj samoupravi u pojedinim njemačkim saveznim pokrajinama koja dovodi do uspostave "monokratskog tipa lokalnih izvršnih funkcija". ${ }^{20}$ Poseban pristup ulozi lokalne samouprave u okviru sustava njemačke javne uprave, koji uključuje inzistiranje na načelu supsidijarnosti te široku razinu decentraliziranog obavljanja različitih upravnih funkcija, služi kao jedan od primjera koji može pripomoći otklanjanju postojećih nedostataka u okviru lokalne samouprave u Hrvatskoj, i uspostavu dobrih praksi kojima je cilj podizanje kvalitete i poboljšavanje efikasnosti u obavljanju lokalnih upravnih djelatnosti u Hrvatskoj.

Ovaj organizacijski ustroj, zajedno sa sličnim organizacijskim modelima u Austriji i Sloveniji, utjecao je na stvaranje hrvatskog modela jakog načelnika, gradonačelnika i župana koji svoje nadležnosti crpi iz prijašnjih nadležnosti koje su imala općinska, gradska i županijska

19 Ova su iskustva ponajprije usmjerena na pitanje odnosa između gradonačelnika kao čelnog čovjeka u jedinici lokalne samouprave i nositelja izvršne vlasti s jedne i gradskog vijeća s druge strane, kao predstavnika građana, koji treba artikulirati normativne okvire kojima se uređuje život u lokalnoj zajednici. U tom smislu postavlja se pitanje uspostave političke ravnoteže između ovih dviju institucija, koja bi trebala osigurati artikulaciju i profiliranje različitih interesa u lokalnoj zajednici. Kao posebno važno otvara se pitanje dijaloga između predstavničkog tijela s jedne i izvršnog tijela s druge strane, kako bi se izbalansirala ravnoteža interesa i osigurao stabilan razvoj zajednice. U praksi je teško postići ovaj balans jer je s jedne strane potrebno stvoriti pretpostavke za relativno jednostavnu smjenu općinskih načelnika i gradonačelnika, kada se u vezi s tim pitanjem ispune pretpostavke definirane zakonskim i(ili) statutarnim propisima. Valja voditi računa i o okolnosti kako neposredno izabrani načelnici i gradonačelnici crpe demokratski legitimitet stečen na izravnim izborima od strane građana pa razlozi na temelju kojih se može pokrenuti procedura opoziva, kao i sama procedura opoziva - moraju biti jasni, nedvosmisleni i unaprijed vrlo precizno regulirani. Predstavnička tijela u jedinicama lokalne samouprave imaju pak važnu i značajnu ulogu u uređivanju regulatornog okvira kroz koje se kanaliziraju društveni interesi građana od lokalnog značaja. U tom smislu ona predstavljaju korektiv, pa i branu samovoljnom postupanju načelnika i gradonačelnika, koji, s obzirom na samu prirodu izvršne vlasti, raspolažu snažnim upravnim instrumentima za provedbu različitih lokalnih politika. 
poglavarstva kao kolektivna izvršna tijela, u kojima je načelnik, gradonačelnik i župan, kao njihov čelni čovjek, imao ulogu prvog među jednakima, dok je odgovornost za implementaciju lokalnih politika bila kolektivna i ovisila je o većinskoj volji članova poglavarstva. Uvođenjem neposrednog izbora načelnika, gradonačelnika i župana, kao objedinjavanjem ovlasti kojima su prije raspolagala općinska, gradska i županijska poglavarstva u osobi načelnika, gradonačelnika i župana, stvoren je model jakoga gradonačelnika kao nositelja izvršne vlasti koji crpi snažan politički legitimitet s jedne strane, a s druge raspolaže s jakim izvršnim ovlastima koje mu omogućavaju operativno upravljanje izvršnim funkcijama u jedinici lokalne samouprave. Ipak, postavlja se pitanje je li ovakav model uvijek prikladan, posebice u situaciji kada postoje određeni demokratski deficiti na lokalnoj razini. Ti se deficiti posebno očituju u situaciji u kojoj se ovlasti gradonačelnika, kao nositelja izvršne vlasti, pretežu nad ovlastima predstavničkog tijela, kao glavnog tijela koje zastupa i reprezentira interese građana, među ostalim, i interese koji se tiču financiranja jedinica lokalne samouprave, kao i ukupnih troškova koji padaju na teret građana. Postavlja se pitanje bi li, sukladno demokratskim načelima i tradiciji demokratskih političkih poredaka, predstavnička tijela koja reprezentiraju interese građana, trebala biti presudna u definiranju financijskog opterećenja građana u jedinici lokalne samouprave, što uključuje i ovlast donošenja proračuna, kao i mogući konflikt s gradonačelnikom, kao predstavnikom lokalne izvršne vlasti, koji ne mora prihvatiti mogućnost modificiranja troškova od strane predstavničkog tijela. Upravo je to i temeljna linija razgraničenja između uloge predstavničkih i izvršnih tijela, gdje predstavnička tijela trebaju zaštititi interese građana, dok izvršna tijela trebaju imati inicijativu u provođenju aktualnih političkih odluka, važnih za svakodnevne interese građana. Kako bi zaštitili svoje interese, građani bi trebali imati mogućnost snažnog utjecaja na predstavnička politička tijela, koja izravno zastupaju njihove interese, i preko tih tijela mogućnost utjecaja na razvoj lokalne zajednice. U tom smislu procedura donošenja proračuna predstavlja jedan vrlo važan korak, koji pokazuje koliko su uistinu samostalna predstavnička tijela u jedinicama lokalne samouprave u procesu donošenja održivih godišnjih proračuna. Ovo pitanje bi trebalo biti ključno u sagledavanju odnosa na relaciji gradonačelnik - vijeće. Naime, gradonačelnik prema svojoj ulozi predstavlja eksponenta izvršne vlasti koji raspolaže različitim upravnim alatima potrebnim za provedbu političkih odluka. $S$ druge strane, gradsko vijeće je kolektivno tijelo koje predstavlja i zastupa interese građana te bi, kao jednom od temeljnih poluga pritiska na izvršnu vlast, trebalo raspolagati s mogućnošću da definira proračune u jedinicama lokalne samouprave jer je riječ o temeljnim dokumentima koji uređuju strukturu javne potrošnje u lokalnoj samoupravi. Ova struktura lokalne javne potrošnje predstavlja naličje upravne djelatnosti i djelovanja izvršnih tijela u proračunskoj godini. Stoga proces predlaganja i donošenja lokalnih proračuna predstavlja jedno od najsnažnijih sredstava pritiska i korekcije u djelovanju lokalne izvršne vlasti od strane lokalnih predstavničkih tijela, i kao takvo, jedan od najsnažnijih mehanizama za uravnoteženje i institucionalizaciju političkih procesa. Valja istaknuti kako predstavnička tijela crpe legitimitet za snažnije sudjelovanje u procesu oblikovanja strukture proračuna, kako na prihodnoj tako i na rashodnoj razini, iz same okolnosti da predstavljaju građane kao lokalne porezne obveznike, koji na temelju poreznih izdvajanja financiraju lokalnu samoupravu pa samim time i očekuju da njihovi reprezentanti u predstavničkom tijelu na odgovarajući način zastupaju njihove pravne interese. $S$ druge strane, i neposredno izabrani načelnici, gradonačelnici i župani imaju odgovornost prema biračima glede provođene lokalnih razvojnih politika na temelju kojih su dobili izbore. Potrebno je pomiriti ova dva, često suprotstavljana interesa: potrebu i interes 
da se osigura transparentan sustav financiranja lokalnih javnih potreba, gdje će biti ugrađeni kontrolni mehanizmi koji će omogućiti predstavničkom tijelu, kao reprezentantu građana, mogućnost adekvatnog nadzora nad financijskim tijekovima. S druge strane, potrebno je osigurati neposredno izabranim čelnicima mogućnost da u okviru zakonskih i statutarnih uvjeta mogu realizirati programske ciljeve svojih politika i da pri tome ne budu blokirani u svome radu od strane predstavničkog tijela, slijede li unaprijed definirane institucionalne mehanizme koji pomažu kanalizirati različite, a katkad i suprotstavljene interese koje mogu kanalizirati predstavnička i izvršna tijela, kao institucije koje polaze s različitih polazišta i teže ostvarivanju ciljeva koji mogu, ali i ne moraju, biti međusobno kompatibilni. U tom smislu otvara se i pitanje razrješavanja konflikta koji postoji u slučaju da se predstavničko i izvršno tijelo nađu na suprotnim pozicijama. Više je različitih mehanizama za razrješavanje ovog konflikta, od kojih se kao jedan navodi istodobni prestanak mandata u slučaju nepostojanja suglasnosti za usvajanje godišnjeg proračuna, dok bi drugi predstavljao proces opoziva općinskog načelnika, gradonačelnika i župana u slučajevima predviđenim zakonom. ${ }^{21}$

Zbog toga se i nastoje podijeliti ovlasti u procesu donošenja lokalnog proračuna, kako bi se osigurala mogućnost aktivne participacije svih dionika u procesu pregovaranja i artikuliranja različitih političkih interesa te stvorio prostor za donošenje mogućih kompromisnih rješenja u procesu kohabitacije između predstavničkih i izvršnih tijela.

\section{KOMPARATIVNI PRIKAZ MODELA IZBORA LOKALNIH IZVRŠNIH TIJELA}

\subsection{MODELI IZBORA LOKALNIH IZVRŠNIH TIJELA U POJEDINIM NJEMAČKIM SAVEZNIM POKRAJINAMA}

U Njemačkoj postoji više različitih modela izbora lokalnih izvršnih tijela koji mogu varirati ovisno o tome o kojoj je njemačkoj saveznoj pokrajini riječ. Načelno gledajući, postoji mogućnost izravnog izbora gradonačelnika od strane građana, ali isto tako i mogućnost da se pozicija gradonačelnika generira izborom od strane članova predstavničkog tijela u jedinici lokalne samouprave.

U Njemačkoj, u velikim gradovima postoji više različitih tipova gradonačelnika, koji se biraju za obnašanje različitih službi (npr. gradonačelnik za gradnju, gradonačelnik za socijalne poslove i sl.). Njima je nadređen tzv. nadgradonačelnik (Oberburgermeister). U Hamburgu se koristi naziv Erste Burgermeister za šefa pokrajinske vlade. ${ }^{22}$

21 U slučaju opoziva, za njegovu se uspješnost u relevantnoj literaturi navode kao bitne sljedeće značajke: jednoglasno prihvaćanje prijedloga za opoziv u vijeću uz konsenzualnu odluku svih stranaka, uključujući i gradonačelnikovu (ovdje se očekuje puna ili barem djelomična potpora za prijedlog opoziva), odgovornost gradonačelnika zbog osobnih i političkih pogrešaka te manji broj stanovnika u općini u smislu lakšeg postizanja zahtijevanog broja glasova birača za opoziv. Kod neuspješnih postupaka postoje značajke poput nedovoljnog broja glasova za pokretanje postupka opoziva, uz okolnost da i gradonačelnikova stranka ne prihvaća prijedlog, nedostatak potpore birača za prijedlog opoziva, ili nedovoljna izlaznost birača, uzrokovana visokim izlaznim cenzusom. O tome više u Podoljnjak, R., Gradonačelnik i vijeće, Piprom, Varaždin, 2010., str. 147.

22 Wehling, H. G., Kommunalpolitik in der Bundesrepublik Deutschland - Eine Einführung, u: Kost, A.; Wehling, H. G. (ur.), Kommunalpolitik in den deutschen Ländern, VS Verlag für Sozialwissenschaften, Weisbaden, 2010., str. 7.-18. 
Izvršne ovlasti kojima raspolaže gradonačelnik u jedinicama lokalne samouprave u Njemačkoj obično su sljedeće: predsjedava gradskom vijeću te je voditelj gradske uprave, ${ }^{23}$ on je odgovoran za pripravnost i izvršavanje političkih odluka donesenih od strane predstavničkog tijela, predstavlja lokalnu zajednicu, nadzire pružanje lokalnih javnih usluga, ${ }^{24}$ odgovoran je za stvarno obavljanje različitih javnih funkcija. Gledajući po njemačkim saveznim pokrajinama, situacija se razlikuje od jedne do druge. U nastavku teksta dat će se pregled strukture izvršnih tijela u lokalnoj samoupravi u Njemačkoj, Austriji, dijelovima Italije, Nizozemskoj i Švicarskoj.

U pokrajini Baden-Wittemberg gradonačelnik obnaša dužnost predsjednika predstavničkog tijela te je na čelu lokalnih upravnih tijela. ${ }^{25}$ On predstavlja jedinicu lokalne samouprave prema van. Mandat gradonačelniku traje osam godina. Lokalno zakonodavstvo pokrajine Baden-Wittemberg uspostavlja tzv. Južnonjemački vijećnički ustroj. ${ }^{26}$

U Bavarskoj je biran prvi gradonačelnik (Erste Bürgmeister) u nekoj jedinici lokalne samouprave. Mandat mu traje šest godina. ${ }^{27}$ Bira se apsolutnom većinom, između dva kandidata u drugom krugu, ako nijedan kandidat ne dobije potrebnu većinu u prvom krugu. Pravna podloga na temelju koje se provode izbori jest Zakon o bavarskim općinskim i kotarskim izborima. ${ }^{28}$ Prvi gradonačelnik predstavlja i zastupa općinu, vodi sjednice predstavničkog tijela u jedinicama lokalne samouprave te izvršava njegove odluke. U općinskom i gradskom vijeću ima i pravo glasa. U autonomnim općinama i većim okružnim gradovima ima status nadgradonačelnika (Oberbürgermeister). U ovim općinama kao i u općinama koje funkcioniraju u okviru okruga, a imaju više do 5.000 stanovnika, u pravilu je dužnosnik na određeno vrijeme. U općinama koje djeluju u okviru okruga, a imaju između 5.000 i 10.000 stanovnika, gradonačelnik obnaša dužnost volonterski ako predstavničko tijelo najkasnije 90 dana prije izbora za gradonačelnika donese da se dužnost obnaša volonterski. U općinama koje djeluju u okviru okruga, a imaju do 5.000 stanovnika, gradonačelnik obnaša dužnost volonterski ako predstavničko tijelo ne donese odluku najkasnije 90 dana prije izbora, da je gradonačelnička dužnost profesionalna. Drugi, kao eventualni i treći gradonačelnik biraju se neizravno, od strane predstavničkog tijela jedinice lokalne samouprave. ${ }^{29}$

U pokrajini Brandenburg gradonačelnici se od 1993. godine biraju izravno. U samostalnim gradovima, ${ }^{30}$ koji samostalno obavljaju lokalne djelatnosti neovisno o okrugu, bira se nadgra-

23 Ovdje valja napomenuti kako je u saveznoj državi Schleswig-Holstein samo na čelu gradske uprave, Donjoj Saskoj može biti predsjednik gradskog vijeća te član gradskog vijeća.

24 Bilo da nadzire pružanje usluga od tijela jedinica lokalne samouprave, bilo da nadzire pružanje usluga koje pružaju privatnopravna tijela, u jednom od modela suradnje $s$ javno-pravnim tijelima.

25 Wehling, H. G., Kommunal Politik in Baden-Württenberg, u: Kost, A.; Wehling, H. G. (ur.), Kommunalpolitik in den deutschen Ländern, VS Verlag für Sozialwissenschaften, Weisbaden, 2010., str. 21.-39.

26 D. Lozina, referirajući se na Južnonjemački vijećnički ustroj, navodi kako su temeljne karakteristike takvog ustroja okolnost da građani biraju predstavničko tijelo, da neposrednim izborima biraju gradonačelnika, da gradonačelnik predsjeda općinskim vijećem te je na čelu lokalne uprave, a da ostale članove izvršnog tijela biraju članovi predstavničkog tijela. O modelu Južnonjemačkog vijećničkog ustroja vidi više u: Lozina, D., Lokalna samouprava - Poredbeno i hrvatsko iskustvo, Pravni fakultet Sveučilišta u Splitu, Split, 2004., str. 26.

27 Fuchs, G., Komunal Politik in Freistaat Bayern, u: Kost, A.; Wehling, H. G. (ur.), Kommunalpolitik in den deutschen Ländern, VS Verlag für Sozialwissenschaften, Weisbaden, 2010., str. 40.-62.

28 Bayerischer Gemeinde - und Landkreiswahlgesetz.

29 Usp. Lorig, W. G., Moderne Kommunalverwaltung in Deutschland, VS Verlag für Sozialwissenschaften, 2014. str. 12 
donačelnik (Oberbürgermeister). ${ }^{31} \mathrm{U}$ općinama koje su podređene okrugu, dužnost gradonačenika je počasna. U općinama koje su neovisne u obavljanju djelatnosti o okrugu, gradonačelničko mjesto je profesionalna funkcija, prema kojoj je gradonačelnik glavni službenik jedinice lokalne samouprave, izabran na određeno vrijeme. Počasni gradonačelnik se zajedno s predstavničkim tijelom jedinice lokalne samouprave bira na mandatno razdoblje od pet godina. Gradonačelnici i nadgradonačelnici koji svoju službu trebaju obnašati profesionalno, birani su na mandat u trajanju od osam godina. Biraju se apsolutnom većinom od ukupnog broja valjanih glasova, a ako nitko u prvom izbornom krugu ne dobije potrebnu natpolovičnu većinu, biraju se u novom izbornom krugu između kandidata koji su u prvom krugu dobili najveći broj glasova. Ova većina mora uključivati najmanje $15 \%$ od ukupnog broja glasača u jedinici lokalne samouprave. $^{32}$

U pokrajini Mecklenburg-Zapadno Pomorje gradonačelnici se biraju izravno od 1999. godine. U gradovima koji su upravno neovisni o okrugu u obavljanju svojih ovlasti postoji jedan nadgradonačelnik. Status neovisnih gradova nakon reforme područne samouprave (Kreisgebitsreform) od 2011. godine zadržali su samo Rostock i Schwerin. ${ }^{33}$ Trajanje službe gradonačelnika prema općinskom izbornom pravu iznosi najmanje sedam a najviše devet godina. Izbor gradonačelnika neovisan je o izboru predstavničkog tijela u jedinici lokalne samouprave, čiji mandat pak traje pet godina. ${ }^{34}$ Izravno birani gradonačelnici mogu biti opozvani samo na temelju volje građana koji su ih birali.

U Donjoj Saskoj gradonačelnička funkcija u općinama nosi naziv Samtgemeindebürgermeister..$^{35} \mathrm{U}$ samostalnim gradovima neovisnima o okrugu, velikim samostalnim gradovima, kao i gradu Hannoveru, gradonačelnička funkcija nosi naziv nadgradonačelnik. ${ }^{36}$ Gradonačelnik se bira posebno, od strane članova gradskog vijeća. Najnovije zakonske novele iz 2016. godine, uvele su sinkronizirani mandat gradonačelnika i gradskog vijeća, koji traje pet godina. ${ }^{37} \mathrm{U}$ tom smislu planiraju se najkasnije od 2021. godine održati zajednički izbori za gradonačelnika i gradsko vijeće.

U Sjevernoj Rajni Vestfaliji gradonačelnik je na čelu lokalne uprave te se bira na tu komunalnu dužnost na određeno mandatno razdoblje. ${ }^{38}$ Do 1994. godine postojala je podjela na šefa uprave i predstavnika općine u svim pravnim i upravnim područjima s jedne ${ }^{39}$ i počasnog gradonačelnika s druge strane, koji su ujedno predsjednici gradskog vijeća. Ovaj sustav

31 Künzel, W., Kommunal Politik in Brandemburg, u Kost, A.; Wehling, H. G. (ur.), Kommunalpolitik in den deutschen Ländern, VS Verlag für Sozialwissenschaften, Weisbaden, 2010., str. 79.-119.

32 Usp. Illy, A., Kommunale Institutionen und öffentliche leistungen, Springer Gabler Verlag, 2015., str. 57.-60.

33 Meyer, H., Kommunal Politik in Mecklenburg-Vorpomeranien, u: Kost, A.; Wehling, H. G. (ur.), Kommunalpolitik in den deutschen Ländern, VS Verlag für Sozialwissenschaften, Weisbaden, 2010., str. 187.-204.

34 Naziv predstavničkog tijela u općinama je općinsko vijeće.

35 Ovaj naziv je teško prevesti jer bi pojam Samtgemeinde značio integrirajuću zajednicu, pa bi naziv u cijelosti trebao značiti gradonačelnik u integrirajućoj zajednici.

36 Hoffman, P., Kommunal Politik in Niedersachsen u Kost, A.; Wehling, H. G. (ur.), Kommunalpolitik in den deutschen Ländern, VS Verlag für Sozialwissenschaften, Weisbaden, 2010., str. 205.-230.

37 Prije je mandat gradonačelnika trajao osam godina, a vijeća pet godina te se mandati nisu poklapali, što se pokazalo nefunkcionalnim zbog okolnosti da aktualni gradonačelnik nije nužno morao imati potporu novoizabranih vijećnika.

38 Kost, A., Kommunal Politik in Nordrhein-Westfalen, u: Kost, A.; Wehling, H. G. (ur.), Kommunalpolitik in den deutschen Ländern, VS Verlag für Sozialwissenschaften, Weisbaden, 2010., str. 231.-254. 
uspostavljen je nakon Drugog svjetskog rata od strane Britanskih okupacijskih vlasti. Bio je poznat i kao "Komunalni sustav s dva vrha". ${ }^{40}$ Nakon napuštanja ovog sustava, uvodi se model prema kojem se gradonačelnik bira posredno, od strane članova gradskog vijeća. Od općinskih izbora iz 1999. slijede izravni izbori za gradonačelnika u gradovima i općinama, na kojima ga građani biraju na mandatno razdoblje u trajanju od šest godina. Kroz Zakon o jačanju lokalne demokracije ${ }^{41}$ došlo je do skraćivanja gradonačelničkog mandata sa šest na pet godina. Od 2020. godine bit će povezani izbori za gradonačelnika te gradsko i općinsko vijeće.

U Falačkom Porajnju općine su međusobno povezane u savez općina koji je poznat kao mjesna općina. Glava u jednoj mjesnoj općini mjesni je gradonačelnik koji tu dužnost obnaša počasno. ${ }^{42}$ Uloga povezivanja više općina u savez općina zajednička je lokalna administracija koja pruža logističku potporu općinama povezanima u savez općina u svakodnevnom obavljanju lokalnih poslova.

U Saarlandu izbor gradonačelnika uređen je Zakonom o komunalnoj samoupravi. ${ }^{43}$ Kandidati za gradonačelničku dužnost u prvom izbornom krugu moraju dobiti više od polovice izlaznih i valjanih glasova. ${ }^{44}$ Ako ne mogu u prvom krugu osigurati potrebnu većinu, u drugi krug ulaze dvojica kandidata s najvećim brojem glasova iz prvog kruga. Opoziv gradonačelnika pokreće se od strane gradskog vijeća. Za njegov opoziv treba se izjasniti većina građana na referendumu, na kojem izlaznost treba iznositi najmanje $30 \%$ birača upisanih u birački popis. Samo je jedanput dosad u Saarlandu zabilježen do kraja provedeni postupak koji je završio opozivom. ${ }^{45}$

U Saskoj se od 1994. godine gradonačelnik bira izravno na sedam godina. U velikim gradovima upravlja gradonačelnik koji nosi naslov nadgradonačelnik (Oberbürgermeister). U općinama s više od 5.000 stanovnika gradonačelnik je glavni službenik na određeno vrijeme. ${ }^{46}$ U malenim općinama funkcija gradonačelnika je volonterska i počasna, dok je u gradovima i općinama s više od 2.000 stanovnika moguće gradonačelničku dužnost obavljati profesionalno, u svojstvu glavnog općinskog službenika, izabranog na određeno vrijeme. Zamjenika gradonačelnika bira gradsko ili općinsko vijeće na sedam godina. U većim jedinicama lokalne samouprave njegova je dužnost profesionalna, dok je u manjima počasna. ${ }^{47}$

U pokrajini Schleswig-Holstein gradonačelnik se u većim gradovima bira izravno na mandatno razdoblje od šest do osam godina. Dužina mandata uređena je statutom svake jedinice

\footnotetext{
$40 \quad$ Na njemačkom kommunale Doppelspitze.

41 Na njemačkom Das gesetz zur Stärkung der kommunalen Demokratie.

42 Oster, R.; Stubenrauch, H., Kommunalpolitik in Rheinland-Pfalz, u: Kost, A.; Wehling, H. G. (ur.), Kommunalpolitik in den deutschen Ländern, VS Verlag für Sozialwissenschaften, Weisbaden, 2010., str. 255.-269.

43 Na njemačkom Kommunalselbstverwaltungsgesetz.

44 Wohlfarth, J., Kommunalpolitik in Saarland, u: Kost, A.; Wehling, H. G. (ur.), Kommunalpolitik in den deutschen Ländern, VS Verlag für Sozialwissenschaften, Weisbaden, 2010., str. 270.-281.

45 Wolfgang Stengel, gradonačelnik općine Schiffweiler 2010. godine.

46 Rehfeld-Staudt, A.; Rellecke, W., Kommunalpolitik in Freistaat Sachsen, u: Kost, A.; Wehling, H. G. (ur.), Kommunalpolitik in den deutschen Ländern, VS Verlag für Sozialwissenschaften, Weisbaden, 2010., str. 282.-306.

47 Usp. Hendler, R., Grundbegriffe der Selbstverwaltung, u: Mann, T.; Püttner, G.(ur.), Handbuch der kommunalen Wissenschaft und Praxis. Berlin, Heidelberg: Springer, 2007., str. 3.-22.
} 
lokalne samouprave. ${ }^{48} \mathrm{U}$ malim općinama, gdje se dužnost gradonačelnika obnaša počasno, u pravilu se gradonačelnik bira od strane predstavničkog tijela jedinice lokalne samouprave.

U Berlinu, koji je i ujedno i grad i savezna pokrajina, gradonačelnik je u dvostrukoj funkciji: čelnik je grada, ali ujedno i savezne pokrajine. Njega bira pokrajinski parlament Berlina. On predstavlja Senat Berlina, čiji je ujedno i predsjednik. ${ }^{49}$ Zbog toga nosi titulu gradonačelnika, ali i senatora. Trenutačno senatska uprava grada Berlina ima osam senatora, od kojih svaki pokriva određeno upravno područje. Tako imamo Senatsku upravu za rad, integraciju i žene, Senatsku upravu za obrazovanje, mlade i znanost, Senatsku upravu za financije, Senatsku upravu za zdravstvo i socijalu, Senatsku upravu za unutarnje poslove i šport, Senatsku upravu za pravosuđe i zaštitu potrošača, Senatsku upravu za razvoj grada i zaštitu okoliša te Senatsku upravu za gospodarstvo, tehnologiju i istraživanja. ${ }^{50}$ Slična je i situacija i u Bremenu, koji je i grad i savezna pokrajina, pa njegove političke institucije predstavljaju i lokalnu, ali i pokrajinsku vlast. ${ }^{51}$ Razlika je jedino u tom što Bremenhaven, luka grada Bremena uživa status zasebnog grada. Predsjednik i članovi Senata, kao izvršno tijelo, biraju se u Pokrajinskom parlamentu Bremena. Predsjednik Senata, i jedan od izabranih članova senata, koji je izabran kao njegov zamjenik, reprezentiraju gradonačelnika Bremena. Njihove su gradonačelničke funkcije odvojene od njihovih pokrajinskih, koje obnašaju kao senatori (odnosno ministri). Grad Bremerhaven ima pak Magistrat i gradonačelnika (Oberbürgemeister). Gradonačelnik je predsjedavajući Magistrata i njihov predstavnik. Dužnost gradonačelnika i članova Magistrata je profesionalna. Gradonačelnika i Magistrat bira gradsko vijeće ${ }^{52}$ kao predstavničko tijelo građana. Mandat im traje šest godina, a bave se lokalnim komunalnim poslovima.

U Hamburgu, koji nosi naslov slobodnog hanzeatskog grada, na čelu grada je prvi gradonačelnik, koji je ujedno i čelnik pokrajinske vlasti. Bira se od strane zastupnika pokrajinskog parlamenta koje biraju građani. ${ }^{53}$ Do 2009. godine mandat prvog gradonačelnika je trajao četiri godine, kada dolazi do promjene Izbornog zakona, kojim se njegov mandat produžuje na pet godina. On imenuje svojeg zamjenika kao drugog gradonačelnika, kao i ostale senatore (odnosno ministre), koji trebaju biti potvrđeni od strane pokrajinske skupštine. Prvi gradonačelnik je predsjednik Senata. Drugi gradonačelnik ima položaj senatora, i sudjeluje, kao i drugi senatori, u procesu donošenja odluka. Isto tako, kao i ostali senatori, vodi jedno od senatskih tijela te je odgovoran za obavljanje upravnih djelatnosti koje su u okviru nadležnosti tog tijela. Grad-država Hamburg je upravno-teritorijalno podijeljen na sedam upravnih okruga na čelu kojih su voditelji okruga, kao čelni ljudi upravnih službi u svakom okrugu. ${ }^{54}$

48 Kellmann, K., Kommunal Politik in Schleswig-Holstein, u: Kost, A.; Wehling, H. G. (ur.), Kommunalpolitik in den deutschen Ländern, VS Verlag für Sozialwissenschaften, Weisbaden, 2010., str. 325.-336.

49 Hoffmann, J.; Schwenkner, F., Kommunalpolitik in Berlin, u Kost, A.; Wehling, H. G. (ur.), Kommunalpolitik in den deutschen Ländern, VS Verlag für Sozialwissenschaften, Weisbaden, 2010., str. 63.-78.

50 Bogumil, J.; Heinelt, H. (ur.), Bürgermeister in Deutschland. Politikwissenschaftliche Studien zu direkt gewählten Bürgermeistern, VS-Verlag, Wiesbaden, 2005.

51 Scherer, M., Kommunal Politik in Bremen, u: Kost, A.; Wehling, H. G. (ur.), Kommunalpolitik in den deutschen Ländern, VS Verlag für Sozialwissenschaften, Weisbaden, 2010., str. 120.-147.

52 Die Stadtverordnetenversammlung.

53 Fraude, A.; Lloyd, M., Kommunal Politik in Hamburg, u: Kost, A.; Wehling, H. G. (ur.), Kommunalpolitik in den deutschen Ländern, VS Verlag für Sozialwissenschaften, Weisbaden, 2010., str. 148.-164.

54 Lüth, E., Hamburgs Schicksal lag in ihrer Hand. Geschichte der Bürgerschaft, Marion von Schröder Verlag, Hamburg, 1966., str. 242. -245 . 


\subsection{PRIMJERI IZBORA LOKALNIH IZVRŠNIH TIJELA U ODABRANIM EUROPSKIM ZEMLJAMA KONTINENTALNO-EUROPSKE TRADICIJE}

U Italiji, u Južnom Tirolu, gradonačelnik se bira izravno. Izborni zakon razlikuje općine s više i manje od 15.000 stanovnika: u gradovima s manje od 15.000 stanovnika svi kandidati za općinsko vijeće ujedno su i kandidati za gradonačelnika, osim ako se takvog statusa izričito ne odreknu. Izabran je onaj kandidat koji osvoji apsolutnu većinu, ako ne u prvom, a ono u drugom krugu izbora. U većim općinama bira se kandidat s jedne liste ili pak jedne koalicije. Zamjenik gradonačelnika je dogradonačelnik, ${ }^{55}$ kojeg bira i nominira gradonačelnik. U općinama s više od 13.000 stanovnika, kao i u onima u kojima to predviđa općinski statut, bira se dogradonačelnik iz reda jezične skupine kojoj gradonačelnik ne pripada. ${ }^{56}$

U Nizozemskoj se gradonačelnici ne biraju na izborima, nego od strane predstavničkog tijela, sukladno broju mandata koje su ostvarili na izborima. Gradonačelnik sa svojim pomoćnicima, od kojih se jedan bira za njegova zamjenika, predstavlja izvršna tijela u jedinici lokalne samouprave. Uz to, gradonačelnik je i na čelu općinskog vijeća. U Nizozemskoj su vođene rasprave o izboru gradonačelnika, pa se 2004. godine dvije trećine građana izrazilo za izravan izbor, dok se jedna trećina izrazila za ostanak postojećeg stanja. Dužnost gradonačelnika u Nizozemskoj obično obnašaju osobe koje su prema svom formalnom obrazovanju pravnici ili upravni stručnjaci. Mandat gradonačelnika traje šest godina, s mogućnošću ponavljanja mandata. Općenito uzevši može se kazati kako se u Nizozemskoj načelno mogu detektirati tri upravljačke razine: središnja državna, regionalna i općinska razina. Na općinskoj razini prevladava diverzitet, koji se očituje u raznolikosti organizacijskih struktura među općinama. Ono što im je zajedničko jest da svaka općina ima općinsko vijeće, općinsko poglavarstvo i gradonačelnika. Općinsko poglavarstvo sastoji se od gradonačelnika i pročelnika. Gradonačelnik je po funkciji predsjednik poglavarstva i u njemu ima pravo glasa. Članovi poglavarstva biraju se iz redova općinskih vijećnika. ${ }^{57}$

U Austriji se u najvećem broju saveznih zemalja gradonačelnik bira izravno, dok se u Donjoj Austriji, Štajerskoj i u Beču bira između članova gradskog vijeća. U Beču je gradonačelnik ujedno i na čelu savezne pokrajine, s obzirom na to da grad Beč uživa status savezne pokrajine. ${ }^{58}$ Gradonačelnik je i član gradskog vijeća kao i pokrajinskog parlamenta. Gradonačelnika koji se ne bira izravno, bira vladajuća većina u predstavničkom tijelu jedinice lokalne samouprave. Gradonačelnik je vodeće tijelo u općini, koje provodi odluke općinskog vijeća. U svom radu bavi se pitanjima vezanim uz područje djelokruga jedinica lokalne samouprave, u okvirima koje postavljaju savezne pokrajine i federacija. Na čelu su lokalnih službi te predstavljaju i zastupaju jedinice lokalne samouprave. U općinama u čijem su sastavu policijske službe, gra-

55 Vizebürgmeister.

56 Više o ovome u: Engl, A.; Pallaver, G.; Alber, E., Politika 2016: Die Gemeinden der Europaregion Tirol-Südtirol-Trentino, Edition Raetia, Auflage 1, 2016.

57 U literaturi se navodi kako je Nizozemska jedna od prvih zemalja koja je na razini lokalne samouprave pokrenula reforme na tragu Novog javnog menadžmenta. Navodi se kako su srednje veliki gradovi poput Tilburga, Defta i Groningena imali vodeću ulogu u implementaciji koncepata Novog javnog menadžmenta Tako su financijski menadžeri i stručnjaci strogo nadzirali financijsku administraciju, lokalno gospodarstvo, i ukupnu u učinkovitost. Temeljno načelo koje je primijenjeno jest "more for less". O tome više u Lozina, D., nav. djelo, str. 28.-29.

58 Pelinka, A., Kommunalpolitik in Österreich, u: Voigt, R., Handwörterbuch zur Kommunalpolitik, Studienbucher zur Sozialwissenschaft, VS Verlag zurSozialwissenschaft, 1984., str. 259.-262. 
donačelnik je na čelu službe ovlaštene za izdavanje službenih dokumenata. Uz gradonačelnika, u svakoj općini se biraju i prvi, drugi ili treći zamjenik gradonačelnika. Broj zamjenika varira ovisno o veličini jedinice lokalne samouprave. Mandat gradonačelnika može varirati i ovisi o svakoj pojedinoj saveznoj pokrajini. Primjerice, u Burgenlandu (Gradišće) traje pet godina, Koruškoj šest godina, Donjoj Austriji pet godina, Gornjoj Austriji šest godina, Salzburgu pet godina, Štajerskoj pet godina, Tirolu šest godina, Vorarlbergu pet godina te u Beču pet godina. Gradonačelnik može biti opozvan, na način da predstavničko tijelo dvotrećinskom većinom glasova pokrene protiv njega postupak opoziva. Smatra se opozvanim ako za njegov opoziv glasa većina od ukupnog broja izašlih na referendum. Za valjanost referenduma potrebna je izlaznost od najmanje 40\% u Burgenlandu, Koruškoj i Voralbergu. U Donjoj Austriji traži se dvotrećinska većina u predstavničkom tijelu. U Gornjoj Austriji i Salzburgu traži se apsolutna većina, dok se u Štajerskoj traži dvotrećinska većina izašlih birača.

U Švicarskoj pojam gradonačelnika napušten je sredinom 19. stoljeća. Danas funkcija analogna ulozi gradonačelnika nosi naziv općinski predsjednik, ali isto tako i gradski predsjednik i sl. ${ }^{59}$ On se bira na neposrednim izborima od strane glasača za čelnu osobu švicarske jedinice lokalne samouprave. Švicarska federacija je ovaj model lokalne samouprave na čelu koji je općinski ili gradski vijećnik, uvela prema uzoru na Francusku. Ova nova organizacija lokalne samouprave uvodi se početkom 19. stoljeća, kada dolazi i do utemeljenja Kantona Aargau, Thurgau, St. Gallen, Waadt i Tessin. Nakon liberalizacije izbornog prava na državnoj razini, dolazi 1830. do liberalizacije izbornog prava i na lokalnoj razini te se uvodi princip demokratskog izbora lokalnog vodstva. Uspostavlja se sustav izvršnog vijeća kojem je na čelu predsjednik, a analogni model primjenjuje se i na kantonalnoj razini. Iznimka je kanton Genf, gdje u općinama manjim od 3.000 stanovnika gradonačelnik je jedino izvršno tijelo. ${ }^{60}$ Općinski predsjednik je odgovoran za vođenje izvršnog vijeća i provođenje političkih odluka. Općinskog predsjednika bira se izravno na lokalnim izborima kroz mjesni zbor građana, ${ }^{61}$ ili neizravno u općinskom parlamentu. Trajanje mandata varira između dvije i pet godina te ima snažne ovlasti u obavljanju lokalnih poslova koji su mu stavljeni u nadležnost. On je na čelu lokalnih upravnih tijela i odgovoran je za njihov rad. Zbog niza različitih poslova koji se obavljaju na lokalnoj razini i kompleksnih znanja koje predsjednik općinskog vijeća danas treba imati, postoji izražen trend ka profesionalizaciji obavljanja ove dužnosti.

\subsection{ANALIZA STANJA}

Iskustva vezana uz način izbora načelnika i gradonačelnika ovise o različitim uvjetima u različitim zemljama pa ta iskustva nisu jednoznačna i mogu se komparirati samo uvjetno, vodeći

59 Gemeindepräsident, Stadtpräsidant, Gemeindeammann, Stadtammann, Talammann, Bezirkshauptmann i sl.

6 Usp. Linder, W., Kommunalpolitik in der Schweiz, u: Voigt, R., Handwörterbuch zur Kommunalpolitik, Studienbucher zur Sozialwissenschaft, VS Verlag zurSozialwissenschaft, 1984., str. 262.-265.

61 Gemeindeversammlung. Ovo je oblik neposredne demokracije koji postoji u zemljama njemačkog govornog područja u malenim lokalnim zajednicama, s malim brojem stanovnika, zbog kojeg nema potrebe za postojanjem predstavničkog tijela, kao oblika posredne demokracije. 
računa i o okolnostima u kojima su nastajala. ${ }^{62}$ Ona ovise o povijesnim okolnostima, društvenom i gospodarskom razvoju, demokratskim tradicijama, snazi lokalnih jedinica i sl. Valja napomenuti kako katkad i povijesna iskustva imaju snažan utjecaj na razvoj pojedinih političkih i upravnih sustava. Takva je primjerice situacija u SR Njemačkoj, gdje je nakon Drugog svjetskog rata iskustvo izgradnje državnih institucija išlo u pravcu odozdo prema gore, na način da su prvo ustrojene i obnovljene jedinice lokalne samouprave koje su preuzele na sebe organizaciju i obavljanje osnovnih upravnih funkcija u lokalnim zajednicama. Nakon toga slijedi uspostava pojedinih saveznih pokrajina koje se na kraju udružuju u federalni savez. Upravo zbog toga lokalna samouprava ima izuzetno značajnu ulogu u funkcioniranju sustava javne uprave u Njemačkoj, za koju se može reći da i danas u pravilu nastoji dosljedno provoditi načelo supsidijarnosti te decentralizirati obavljanje upravnih funkcija, kako bi što više osnažila značenje i ulogu lokalne samouprave u obavljanju društvenih poslova. Zbog toga iskustvo organizacije lokalne samouprave, kao i bogatstvo odnosa koji postoje između predstavničkih i izvršnih tijela u jedinicama lokalne samouprave, ukazuje kako modaliteti odnosa između izvršnih i predstavničkih institucija mogu biti različiti. Njemački sustav lokalne samouprave tako dovodi do različitih rješenja u odnosu između izvršnih i predstavničkih tijela, čime se i tako ukazuje na smjer kojim su se gradile demokratske političke institucije u njemačkom društvu. Načelno se mogu izdvojiti dva temeljna modela koja su karakteristična za njemačku upravu: monokratski tip lokalnih izvršnih tijela te kolegijalni tip lokalnih izvršnih tijela. Kod monokratskog tipa lokalnih izvršnih tijela izvršne su ovlasti koncentrirane u rukama načelnika, odnosno gradonačelnika, kao samostalnog tijela koje provodi izvršne odluke u jedinicama lokalne samouprave. Kod kolegijalnog tipa lokalnih izvršnih tijela, naglasak je na kolegijalnom izvršnom tijelu, koje zajednički donosi izvršne odluke, koje se zatim implementiraju preko lokalnih upravnih tijela. Upravo zbog toga se pozivalo na oprez pri uvođenju modela neposrednog izbora gradonačelnika u Hrvatskoj, zbog okolnosti da se nije u dovoljnoj mjeri analizirao problem kohabitacije između izvršnih i predstavničkih institucija. Ovaj problem se otvara u dvije dimenzije. Kod kolegijalnog tipa lokalnih izvršnih tijela, veću ili manju ulogu u njihovu izboru ima predstavničko tijelo jedinice lokalne samouprave, pa je legitimitet kolegijalnih izvršnih tijela načelno izveden iz legitimiteta predstavničkih tijela. Drugu dimenziju predstavlja odnos između izvršnih, političkih tijela u jedinicama lokalne samouprave te profesionalnih, upravnih tijela. Dok je kod kolegijalnih izvršnih tijela transmisija političkih odluka relativno olakšana jer su obično članovi kolektivnih izvršnih tijela zaduženi po pojedinim upravnim područjima, kod monokratskog tipa lokalnih izvršnih tijela javlja se problem transmisije političkih odluka koji se jedino može prevladati uvođenjem instituta savjetnika koji bi, lišeni legitimiteta predstavničkog tijela, a crpeći legitimitet monokratskog izvršnog tijela, osigurali premosnicu na profesionalna upravna tijela u jedinicama lokalne samouprave. Alternativa ovakvom modelu rješavanja problema transmisije političkih odluka povezivanje je položaja čelnika pojedinih upravnih tijela u jedinici lokalne samouprave (pročelnika i njihovih zamjenika) s pozicijom izabranih čelnika jedinica lokalne samouprave. Glede tog problema u literaturi može se naći razmišljanje kako bi tom

62 Koprić tako navodi primjere različitih iskustava više različitih zemlja. U Sloveniji su jedinice lokalne samouprave gotovo paralizirane političkim sukobima između župana i občinskog sveta. U bivšim istočnonjemačkim zemljama veliki je broj neposredno izabranih gradonačelnika koji su opozvani od strane birača. S druge strane, u Italiji je došlo do stabilizacije lokalnih političkih vodstava i manjeg utjecaja političkih stranaka na neposredno izabrane načelnike. Uz to, isticanje načelnika u lokalnoj jedinici i olakšan pristup medijima osiguravaju im mogućnost lakšeg reizbora. O tome više u: Koprić, I., 2006., str. 321.-322. O južnonjemačkom vijećničkom ustroju više u: Lozina, D., nav. djelo, str. 26. O zemljama i kojima je prisutan neposredan izbor gradonačelnika vidi i u: Ivanišević, S., 2008., nav. djelo, str. 15. 
problemu trebalo prići ostvarivanjem triju načela: načela razmjernosti, prema kojem izborni sustav treba biti kreiran na način da omogući zastupljenost različitih društvenih interesa u predstavničkom tijelu; načela personalizacije, prema kojem bi izborni sustav trebao omogućiti značajan utjecaj birača na izbor načelnika i gradonačelnika te načela stabilnosti, prema kojem bi izborni sustav trebao biti oblikovan na način da osigura stabilno djelovanje i međusobnu suradnju predstavničkih i izvršnih institucija. ${ }^{63}$

S druge strane, postojao je i strah da će uvođenje neposrednog izbora načelnika, gradonačelnika i župana dovesti do "prezidencijalizacije" u lokalnom sustavu upravljanja, u kojoj će predstavnička tijela biti u inferiornijem položaju u odnosu na izvršna tijela. ${ }^{64}$ Ovaj strah od "prezidencijalizacije” dodatno bi mogle ojačati ideje prema kojima bi se izvršnim tijelima, radi povećanja njihove učinkovitosti i operativnosti, mogle osigurati dodatne ovlasti koje bi im omogućile samostalnije vođenje lokalnih politika, neovisno o eventualnom otporu predstavničkih tijela, što s druge strane dovodi do neravnoteže u odnosima između predstavničkih i izvršnih tijela te općenito može narušiti demokratske političke procese u lokalnoj zajednici.

\subsection{ANALIZA PRIMIJENJENIH MODELA IZBORA IZVRŠNIH TIJELA}

Analiza neposrednog izbora gradonačelnika u Njemačkoj pokazuje kako primjena neposrednog izbora gradonačelnika i pravo građana da biraju izravno, značajno mijenja odnose snaga među političkim akterima. Predstavnički sustav, u kojem je težište u donošenju političkih odluka na predstavničkom tijelu, uvođenjem izravnog izbora načelnika, na lokalnoj razini počinje se značajno mijenjati. Tako dolazi do značajnijeg odstupanja glasovanja glasača na lokalnim izborima, od njihova glasanja za pokrajinska i savezna tijela. Izravnim izborom gradonačelnike se počinje promatrati kao lokalne lidere, čija se odgovornost može jasno odrediti. Osim toga, građani raspolažu s važnim instrumentom za pritisak na izravno izabrane gradonačelnike, a to je njihova mogućnost opoziva, koja se u pokrajinama koje su uvele mogućnost izravnog izbora, u značajnoj mjeri i koristila. ${ }^{65}$ Ipak, slabljenje uloge vijeća, kao predstavničkih tijela građana u jedinicama lokalne samouprave, može dovesti do naglašenog prezidencijalizma od strane izravno izabranih gradonačelnika, čime se stvara neravnoteža na relaciji gradonačelnik i gradsko vijeće. Njemačka iskustva pokazuju da iako postoji izraženi trend za uvođenjem neposrednog izbora izvršnih tijela u jedinicama lokalne samouprave, ipak je u značajnoj mjeri prisutan predstavnički sustav, koji građanima u određenoj mjeri otvara mogućnost veće participacije u lokalnoj demokraciji, kroz različita tijela osnovana od strane predstavničkog tijela.

63 O tome više u: Podoljnjak, R., nav. djelo, str. 94.-95.

64 Kao primjer navodi se Italija, u kojoj talijanski lokalni izborni sustav, za kojeg se kaže da uvodi superprezidencijalizam, na način da uvodi stapanje izbora gradonačelnika i članova predstavničkog tijela u jedan izbor i davanjem izborne premije najjačoj listi - gradonačelnikovoj listi, čime se osigurava kohabitacija između predstavničkog tijela i gradonačelnika. Naravno, taj model ne isključuje mogućnost kohabitacijskih sukoba jer pitanje većine u predstavničkom tijelu ovisi o tome je li kandidat za gradonačelnika izabran u prvom ili u drugom krugu te jesu li liste koje su podržavale kandidaturu gradonačelnika osvojile apsolutnu većinu ili ne. O tome više u: Podoljnjak, R., nav. djelo, str. 97.-100.

$65 \mathrm{O}$ tome više u: Wollman, H., The directly elected exegutive major in German local government, u: Berg, R.; Rao, N.(ur.), Transforming Local Political Leadership, Palgrave, str. 34.-38. 


\section{UVOĐENJE MODELA NEPOSREDNOG IZBORA NAČELNIKA, GRADONAČELNIKA I ŽUPANA U HRVATSKI SUSTAV LOKALNE SAMOUPRAVE}

Izmjenama Zakona o lokalnoj i područnoj (regionalnoj) samoupravi iz 2007., 2008. i 2009. godine u Hrvatskoj se ukida općinsko, gradsko i županijsko poglavarstvo kao kolektivno izvršno tijelo, a ovlasti koje je dotad imalo prenose se na načelnika, gradonačelnika i župana. Uvodi se i odredba prema kojoj načelnik, gradonačelnik i župan imaju svoje zamjenike koji se zajedno s njima biraju na neposrednim izborima. Uvodi se također i mogućnost opoziva referendumom od strane građana. Postupak opoziva mogu pokrenuti vlastitom inicijativom građani ili predstavničko tijelo, a odluku o raspisivanju referenduma donosi predstavničko tijelo većinom glasova od ukupnog broja članova predstavničkog tijela. Kao razlozi za raspisivanje referenduma navode se kršenje ili neizvršavanje odluka predstavničkog tijela te nanošenje znatne materijalne štete jedinici lokalne i područne (regionalne) samouprave. ${ }^{66}$ Dva su ograničenja referenduma: referendum se ne može raspisati odmah po izboru načelnika, gradonačelnika i župana, nego je potrebno da od njihova izbora protekne najmanje šest mjeseci te ako je referendum proveden, a oni njime nisu smijenjeni, novi se referendum ne može raspisati najmanje idućih dvanaest mjeseci, od dana održavanja raspisanog referenduma. U praksi se pokazalo da je postupak opoziva praktično nemoguće provesti jer je prema Zakonu o referendumu potrebno da izađe i glasa za smjenu većina od ukupnog broja građana upisanih u birački popis, što je praktično nemoguće jer je odziv građana na lokalne izbore obično manji, a neke sredine imaju specifične okolnosti koje još to dodatno kompliciraju. ${ }^{67}$

Zakonom o izboru općinskih načelnika, gradonačelnika, župana i gradonačelnika Grada Zagreba ${ }^{68}$ propisuje se da kandidat za navedene funkcije mora imati prebivalište od najmanje šest mjeseci na području jedinice lokalne i područne (regionalne) samouprave za koju se kandidira, čime se onemogućila manipulacija s kandidatima koji ne žive u nekoj jedinici lokalne samouprave.

Poseban problem koji se pojavio bilo je imenovanje predstavnika jedinica lokalne samouprave u lokalna poduzeća i javne ustanove. Iako Zakon o trgovačkim društvima jasno i nedvosmisleno utvrđuje da osoba koja predstavlja pravnu osobu ujedno je i zastupa pred drugim pravnim subjektima, a u slučaju jedinica lokalne samouprave te osobe su načelnici, gradonačelnici i župani na temelju Zakona o lokalnoj i područnoj (regionalnoj) samoupravi (članak 42. stavak 1.), Ustavni sud takvo zakonsko uređenje nije prihvatio, nego je tumačio da se ovlast imenovanja u upravna vijeća i nadzorne odbore uređuje statutom jedinice lokalne i područne (regionalne) samouprave. ${ }^{69}$ Nadalje, zakonodavac nije jasno predvidio mogućnost supstitucije nekadašnjeg modela kolegijalnog izvršnog tijela, nego je u praksi došlo do uvođenja funkcije

66 Pod pojmom znatne materijalne štete predviđa se šteta u iznosu od 1\% proračuna jedinice lokalne samouprave u tekućoj godini, a ako 1\% proračuna iznosi više od 500.000,00 kuna, znatnom materijalnom štetom smatra se šteta od 500.000,00 kuna.

67 S autorom ovoga članka kontaktirali su građani i dio lokalnih vijećnika jedne otočke općine u srednjoj Dalmaciji, koji su željeli raspisati referendum jer su bili nezadovoljni radom načelnika. Kao dodatan problem imali su okolnost da je prebivalište imao znatan broj Splićana porijeklom iz njihove općine, koji su ostvarivali čitav niz pogodnosti na otoku kao što su jeftinije trajektne karte, manji porez, naknada troškova prijevoza i sl. 
savjetnika načelnika, odnosno gradonačelnika, koja nije istovjetna s funkcijom člana gradskog poglavarstva. Dok je član gradskog poglavarstva svoj legitimitet crpio iz izbora članova predstavničkog tijela, a odluke donosio na sjednicama u okviru kolektivnog političkog tijela, savjetnik načelnika i gradonačelnika svoju poziciju temelji na povjerenju i odluci gradonačelnika, a njegovo je stajalište savjetodavno i ničim ne obvezuje načelnika i gradonačelnika. Postoji također i mogućnost da nova osoba izabrana na čelnu dužnost želi dovesti vlastiti savjetnički tim. Osim toga postavlja se i pitanje supstituta za općinsko poglavarstvo, uspostavom kolegija, koji bi čelniku izvršnog tijela pomagao u upravljanju jedinicom lokalne samouprave. Zbog toga bi ova pitanja bilo dobro pobliže urediti zakonom, gdje bi se postavile granice ovlasti savjetnika načelnika, gradonačelnika i župana i gdje bi se njegov mandat i trajanje tog mandata poklapao s trajanjem mandata osobe koja ga je imenovala na tu dužnost. Time bi se načelnicima, gradonačelnicima i županima dala mogućnost lakšeg upravljanja jedinicama lokalne samouprave, što posebno dolazi do izražaja u većim jedinicama lokalne samouprave. S obzirom na to da je riječ o funkcijama povezanima uz funkciju čelnika jedinice lokalne samouprave, trebalo bi im omogućiti punu slobodu glede izbora članova savjetničkog tima, ali i eventualne njihove smjene. Alternativno, kako bi se osigurala načelna potpora predstavničkog tijela radu savjetničkog tima gradonačelnika, moglo bi se uvesti institut potvrde članova savjetničkog tima u predstavničkom tijelu.

\section{POKUŠAJ USPOSTAVE RAVNOTEŽE IZMEĐU GRADONAČELNIKA KAO IZVRŠNOG TIJELA I PREDSTAVNIČKIH TIJELA U OPĆINI, GRADU I ŽUPANIJI NA TEMELJU ZAKONSKIH NOVELA IZ 2012. GODINE}

Dana 14. prosinca 2012. godine Hrvatski sabor je donio nove propise vezane uz izbor i ovlasti lokalnih dužnosnika. ${ }^{70}$ Glede izbora i ovlasti načelnika, gradonačelnika i župana dogodilo se više izmjena. Donesen je tako Zakon o lokalnim izborima kojim je objedinjeno lokalno izborno zakonodavstvo.

Što se pak tiče Izmjena i dopuna Zakona o lokalnoj i područnoj (regionalnoj) samoupravi, došlo je do izmjena vezanih uz postupak opoziva te ovlasti načelnika, gradonačelnika i župana.

Glede postupka opoziva uvodi se odredba koja precizira da $20 \%$ birača može zatražiti pokretanje postupka opoziva. Daljnja novina je u tome da predstavničko tijelo mora, ako središnje tijelo državne uprave nadležno za lokalnu i područnu (regionalnu) samoupravu utvrdi ispravnost podnesenog prijedloga od strane građana, raspisati referendum u roku od 30 dana od dostavljenog mišljenja središnjeg tijela. ${ }^{11}$ Produžena je nemogućnost raspisivanja referen-

70 Narodne novine, broj 144/2012.

71 Prema čl. 24. Zakona o lokalnoj i područnoj (regionalnoj) samoupravi najmanje 20\% građana upisanih u birački popis jedinice lokalne samouprave podnosi zahtjev za održavanje referenduma predstavničkom tijelu jedinice lokalne samouprave. U roku od osam dana predstavničko tijelo prosljeđuje taj dopis središnjem tijelu državne uprave nadležnom za poslove lokalne i područne (regionalne) samouprave, koje mora u roku od 60 da utvrditi ispravnost podnesenog prijedloga. Ako se utvrdi ispravnost podnesenog prijedloga, odluka se dostavlja predstavničkom tijelu, koje je dužno raspisati referendum u roku od 30 dana od dana zaprimanja odluke. 
duma novoizabranog načelnika, gradonačelnika i župana sa šest na dvanaest mjeseci od dana njihova izbora, a za donošenje odluke o opozivu prema novim odredbama dovoljno je da za opoziv glasa najmanje trećina birača upisanih u birački popis.

Također se predviđa održavanje izbora ako je mandat načelniku, gradonačelniku i županu prestao prije isteka mandata, a od početka mandata je proteklo manje od dvije godine. Ako je proteklo više od dvije godine, njegovu dužnost preuzima njegov zamjenik, i to onaj koji je naveden kao prvi na kandidacijskoj listi. Ako mandat prestane i zamjeniku, raspisat će se izbori, a Vlada RH će imenovati povjerenika. Ako je mandat načelniku, gradonačelniku i županu prestao njegovim opozivom, neće ga naslijediti zamjenik, nego će se raspisati izbori, a Vlada će imenovati povjerenika.

Posebno važnu ovlast načelnici, gradonačelnici i župani dobivaju člankom 48. stavkom 6., a to je ovlast imenovanja i razrješenja predstavnika jedinica lokalne samouprave u tijelima javnih ustanova, trgovačkih društava i drugih pravnih osoba, čime stječu mogućnost kontrole njihova poslovanja.

Izmjene Zakona o lokalnoj i područnoj (regionalnoj) samoupravi obuhvatile su i ideju prema kojoj bi, u slučaju neizglasavanja proračuna ili odluke o privremenom financiranju, dolazilo do raspuštanja predstavničkog tijela i razrješenja izvršnog tijela u jedinici lokalne i područne (regionalne) samouprave (čl. 85.a Zakona o lokalnoj i područnoj (regionalnoj) samoupravi). Zanimljivo je da prema zakonskim odredbama, ako gradonačelnik, načelnik i župan koji je jedini ovlašten za predlaganje proračuna, svoj prijedlog i povuče, predstavničko tijelo može donijeti samostalno odluku o privremenom financiranju, ali najdulje za razdoblje od tri mjeseca.

Uz novele Zakona o lokalnoj i područnoj (regionalnoj) samoupravi, donesen je i potpuno novi Zakon o lokalnim izborima, ${ }^{72} \mathrm{u}$ koji su ugrađene odredbe vezane uz izbor predstavničkih i izvršnih tijela u jedinicama lokalne i područne (regionalne) samouprave. I dalje se za kandidate za načelnika, gradonačelnika i župana predviđa obveza prijave prebivališta najmanje šest mjeseci ranije od dana raspisivanja izbora u jedinici lokalne samouprave, a redoviti se izbori održavaju treće nedjelje u svibnju svake četiri godine.

\subsection{DONESENE ZAKONSKE IZMJENE I ODNOS IZMEĐU PREDSTAVNIČKIH I IZVRŠNIH TIJELA U LOKALNOJ SAMOUPRAVI}

Temeljno pitanje koje se željelo urediti navedenim izmjenama jest pitanje odnosa između predstavničkih i izvršnih tijela u jedinicama lokalne samouprave. Dok je prijašnji odnos između predstavničkih i izvršnih tijela bio takav da je načelnik, gradonačelnik i župan bio u dominantnijoj poziciji jer je na temelju odredbi o mogućnosti opoziva bio praktički nesmjenjiv, novim se zakonodavstvom nastoji unijeti određena ravnoteža. Ta se ravnoteža pokušava ostvariti unošenjem odredbe, prema kojoj u procesu donošenja proračuna ravnopravno sudjeluju načelnik, gradonačelnik i župan kao nositelji izvršne vlasti te općinsko i gradsko vijeće i županijska skupština kao predstavnici građana. Čelnici izvršne vlasti predlažu, a predstavničko tijelo usvaja proračun i sam proces predstavlja dijalog u kojem se dogovaraju lokalne razvoj- 
ne politike. Interes građana nastoji se zaštititi preko predstavništva građana, dok se razvojna dinamika u jedinici lokalne samouprave nastoji ostvariti s pomoću operativnih instrumenata koji stoje na raspolaganju čelnicima lokalne izvršne vlasti. U slučaju da navedeni dijalog nije moguće ostvariti, konflikt koji se pojavljuje između predstavničkog i izvršnog tijela razrješuje se novim izborima, čime svako od lokalnih tijela na sebe preuzima dio odgovornosti prema građanima te legitimitet za donesene odluke traži kroz povjerenje građana.

Kao i svako drugo rješenje i ovo je rješenje takve prirode da može biti podložno kritikama. Promatra li se iz perspektive gradonačelnika neposredno izabranog na izborima koji je dobio legitimitet izravno od građana za političke programe i lokalne javne politike koje u mandatu namjerava provoditi, ovakva je pozicija neizdrživa jer je prisiljen ulaziti u različite kompromise i dogovore kako bi osigurao potrebnu većinu za usvajanje proračuna, a često su zahtjevi koji se pred njega postavljaju takve prirode da su u suprotnosti s politikom koju je tijekom izbornog procesa proklamirao. Promatrano iz perspektive članova predstavničkog tijela, ovakvo rješenje je značajno jer osigurava snažan institucionalni pritisak na neposredno izabranog čelnika jedinice lokalne samouprave i osigurava značajniji nadzor nad radom lokalnih tijela. Mogućnost rizika od novih izbora otvara mogućnost konsenzualnog vođenja lokalne politike, uz dosljedno inzistiranje na dijalogu koji je usmjeren prema pomirenju različitih društvenih interesa i postizanju kompromisa prihvatljivih većini u lokalnoj zajednici.

\section{ZAKLJUČAK}

U ovom radu korištenjem metoda komparativne analize i sinteze kritički je razmatran položaj i uloga izvršnih tijela u jedinicama lokalne samouprave, preko inauguracije dvaju temeljnih modela izvršnih tijela: monokratskog i kolegijalnog. Napravljena je komparativna analiza izvršnih tijela u jedinicama lokalne samouprave u Hrvatskoj i Njemačkoj, kao i u odabranim zemljama kontinentalno-europske tradicije. Kroz model monokratskog i kolegijalnog tijela napravljena je sinteza temeljnih obilježja koja oslikavaju položaj lokalnih izvršnih tijela i njihov međuodnos s predstavničkim tijelima, ali i građanima kao nositeljima političkog legitimiteta u lokalnoj zajednici.

Hrvatski sustav lokalne samouprave obilježava specifičan odnos između predstavničkih i izvršnih tijela, koji se posebno odražava kroz pitanja njihove međusobne smjenjivosti, odnosno raspuštanja. S obzirom na to da su na temelju postojećih zakonskih rješenja čelnici $\mathrm{u}$ jedinicama lokalne samouprave bili nesmjenjivi, nova zakonska rješenja uvode ravnotežu između predstavničkih i izvršnih tijela, glede mogućnosti da i gradonačelnici preuzmu dio odgovornosti i uzmu u obzir mogućnost prestanka mandata u slučaju izostanka sporazuma s predstavničkim tijelom, čime i sami dolaze u situaciju da moraju dobro procijeniti i prihvatiti kompromis ili se odlučiti na rizik novih izbora. Drugo, okolnost da su uvjeti predviđeni za postupak opoziva dodatno ublaženi te omogućuju jednostavniju proceduru opoziva, također pridonosi izgradnji demokratskog ozračja u jedinicama lokalne samouprave koje vrše dodatni pritisak na čelnike izvršnih tijela u pravcu razvoja prihvatljivih oblika lokalnog upravljanja. ${ }^{73}$

73 Autor ovog rada bio je konzultiran od strane građana i građanskih inicijativa u jednoj dalmatinskoj jedinici lokalne samouprave, koji su, izrazito nezadovoljni radom svoga gradonačelnika, željeli inicirati postupak njegove smjene preko gradskoga vijeća. Kako 
S druge strane, olakšavanje uvjeta potrebnih za pokretanje procedure opoziva trebalo je osigurati poduzimanjem mjera koje bi onemogućile potencijalne zlouporabe navedenih instituta. Zbog toga se produžuje poček raspisivanja referenduma za opoziv načelnika, gradonačelnika i župana sa šest mjeseci od dana izbora na dvanaest mjeseci od dana izbora. Ova izmjena je značajna jer pridonosi stabilizaciji odnosa između izvršnih i predstavničkih tijela te potiče njihovu kohabitaciju. Ovakvo će rješenje nesumnjivo stabilizirati odnose u lokalnoj samoupravi i dati dostatan vremenski okvir da se predstavničko i izvršno tijelo pokušaju dogovoriti oko institucionalnih i političkih okvira svog djelovanja. Kako bi se poduzeta mjera učinila efikasnijom, uvodi se i izmjena vezana uz izlaznost birača na izbore, gdje je za odluku o opozivu dovoljno da za nju glasa najmanje trećina glasača upisana u birački popis. Problem kod ove odluke jest u tome što postoje određene jedinice lokalne samouprave gdje su ljudi prijavljeni kako bi ostvarili određena prava i oni faktično dižu postotak glasača koji mora izići na referendum o opozivu, čime pojedini čelnici jedinica lokalne samouprave objektivno dolaze u situaciju da su teže smjenjivi. ${ }^{74}$ I prije je ova odredba stvarala velike probleme u praktičnoj primjeni, jednostavno zbog okolnosti da je zbog čitavog niza objektivnih razloga vrlo teško osigurati izlaznost od najmanje trećine glasačkog tijela.

Sljedeća novina koja osigurava veću operativnost izvršnih čelnika jedinica lokalne i područne (regionalne) samouprave jest njihova ovlast imenovanja predstavnika jedinica lokalne i područne (regionalne) samouprave u tijela lokalnih javnih ustanova, lokalnih trgovačkih društava i drugih pravnih osoba, čime se ostvaruje njihova veća odgovornost u realizaciji lokalnih politika, a sukladno okolnosti da svoj politički legitimitet crpe iz neposrednog izbora od strane građana. Ovdje se kao temeljni problem javlja već analizirana uloga savjetnika imenovanih od strane gradonačelnika, kao i mogućnost uspostave tima gradonačelnika koji bi trebao omogućiti mnogo efikasnije upravljanje lokalnim javnim službama kao i drugim upravnim tijelima koja djeluju u okviru jedinica lokalne samouprave.

Sve navedene novine, koje su ugrađene u hrvatski sustav lokalne samouprave, imale su za cilj povratak ravnoteže između predstavničkih i izvršnih tijela u lokalnoj samoupravi, kao i jasnu podjelu njihovih nadležnosti. Ova se podjela nastojala dosljedno slijediti na način da one ovlasti, poput primjerice imenovanja članova upravnih vijeća javnih ustanova i nadzornih odbora trgovačkih poduzeća, prema svojoj prirodi bliže izvršnim tijelima, budu u nadležnosti izvršnih tijela, dok one ovlasti koje imaju ponajprije nadzorni i kontrolni karakter, budu u ovlasti predstavničkih tijela. Time se nastojala uspostaviti međusobna ravnoteža te efikasan mehanizam međusobne kontrole u radu tijela jedinica lokalne samouprave. Ipak, time nije riješen čitav niz pitanja, poput odnosa između izvršnih tijela i profesionalnih upravnih tijela u okviru jedinica lokalne samouprave. Nadalje, ostala je nedefinirana i uloga savjetnika gradonačelnika u jedinicama lokalne samouprave, a koja se uvodi kao supstitut nakon ukidanja modela kolektivnog izvršnog tijela, a trebao bi olakšati svakodnevni rad i funkcioniranje čelnika jedinice lokalne samouprave, kao monokratskog izvršnog tijela. Ova uloga je tim problematičnija jer nije uopće opsežno pravno razrađena, a u pravnoj i upravnoj praksi je raširena te kao takva predstavlja pravnu prazninu u zakonodavstvu koje uređuje hrvatski sustav lokalne samouprave. Bez njezine temeljitije razrade, uz definiranje ovlasti koje imaju savjetnici gradonačelnika,

je dotični gradonačelnik imao većinu u gradskom vijeću, raspisivanje natječaja nije bilo moguće jer vijećnici nisu imali obvezu prihvatiti prijedlog građana. 
kao deriviranih ovlasti koje proizlaze iz demokratskog političkog legitimiteta izabranog čelnika, teško je očekivati ostvarivanje uloge koja se od savjetnika gradonačelnika očekuje, a to je pozicija glavnih političkih operativaca koji gradonačelniku stoje na raspolaganju u provedbi njegovih političkih odluka te realizaciji političkog programa koji čelnicima jedinica lokalne samouprave predstavlja platformu za političko djelovanje.

Zbog problema koji se pojavljuju u odnosu između predstavničkih i izvršnih tijela u jedinicama lokalne samouprave, realno je očekivati novu, modificiranu fazu glede redefiniranja odnosa u jedinicama lokalne samouprave. Ona bi uključivala pitanje primjene decentralizacije u modernim demokratskim procesima na lokalnoj razini, primjenu načela subsidiranosti, daljnju stabilizaciju odnosa između predstavničkog i izvršnog tijela te općenito jačanje pozicije lokalnih demokratskih političkih institucija koje trebaju osigurati mogućnost suradnje, kako bi se institucionalizacijom političkih procesa osigurala mogućnost za ostvarivanje lokalnih javnih upravnih i financijskih ciljeva.

\section{LITERATURA}

1. Blažević, R., Upravna znanost, Društveno veleučilište u Zagrebu, Zagreb, 2010.

2. Bogumil, J.; Heinelt, H. (ur.), Bürgermeister in Deutschland. Politikwissenschaftliche Studien zu direkt gewählten Bürgermeistern, VS - Verlag, Wiesbaden, 2005.

3. Engl, A.; Pallaver, G.; Alber, E., Politika 2016: Die Gemeinden der Europaregion Tirol-Südtirol-Trentino, Edition Raetia, Auflage 1, 2016.

4. Fraude, A.; Lloyd, M., Kommunal Politik in Hamburg, u: Kost, A.; Wehling, H. G. (ur.), Kommunalpolitik in den deutschen Ländern, VS Verlag für Sozialwissenschaften, Weisbaden, 2010., str. 148.-164.

5. Fuchs, G., Komunal Politik in Freistaat Bayern, u: Kost, A.; Wehling, H. G. (ur.), Kommunalpolitik in den deutschen Ländern, VS Verlag für Sozialwissenschaften, Weisbaden, 2010., str. 40.-62.

6. Hendler, R., Grundbegriffe der Selbstverwaltung, u: Mann, T.; Püttner, G.(ur.), Handbuch der kommunalen Wissenschaft und Praxis. Berlin, Heidelberg: Springer, 2007., str. 3.-22.

7. Hoffman, P., Kommunal Politik in Niedersachsen u: Kost, A.; Wehling, H. G. (ur.), Kommunalpolitik in den deutschen Ländern, VS Verlag für Sozialwissenschaften, Weisbaden, 2010., str. 205.-230.

8. Hoffmann, J.; Schwenkner, F., Kommunalpolitik in Berlin, u: Kost, A.; Wehling, H. G. (ur.), Kommunalpolitik in den deutschen Ländern, VS Verlag für Sozialwissenschaften, Weisbaden, 2010., str. 63.-78.

9. Illy, A., Kommunale Institutionen und öffentliche leistungen, Springer Gabler Verlag, 2015.

10. Ivanišević, S., Izvršne institucije u lokalnoj samoupravi, Institut za javnu upravu, Zagreb, 2008.

11. Ivanišević, S., Teritorijalna osnova lokalne i regionalne samouprave, u: Stručne osnove za reformu lokalne samouprave u Hrvatskoj, Hrvatski pravni centar, Projekt “Zakonski okvir decentralizacije u Hrvatskoj", Zagreb, 2000.

12. Kellmann, K., Kommunal Politik in Schleswig-Holstein, u: Kost, A.; Wehling, H. G. (ur.), Kommunalpolitik in den deutschen Ländern, VS Verlag für Sozialwissenschaften, Weisbaden, 2010., str. 325.-336.

13. Koprić, I., Državna uprava i lokalna samouprava u Hrvatskoj 1990. - 2001. - vladavina prava ili politike?, Zbornik Pravnog fakulteta u Zagrebu, Zagreb, vol. 51, br. 6, 2001. 
14. Koprić, I., Neposredni izbor gradonačelnika i općinskog načelnika, u: Koprić, I. (ur.), Javna uprava. Nastavni materijali, Društveno veleučilište u Zagrebu i Pravni fakultet u Zagrebu, Zagreb, 2006., str. 321.-322.

15. Koprić, I., Stanje lokalne samouprave u Hrvatskoj, Hrvatska javna uprava, vol. 10, br. 3, 2010.

16. Koprić, I., Uloga županija u hrvatskom sustavu lokalne samouprave i uprave 1990-ih godina i perspektive regionalizacije nakon promjene Ustava iz 2000-te godine, Hrvatska javna uprava, vol. 3, br. 1, 2001., str. 63.-87.

17. Kost, A., Kommunal Politik in Nordrhein_Westfalen, u: Kost, A.; Wehling, H. G. (ur.), Kommunalpolitik in den deutschen Ländern, VS Verlag für Sozialwissenschaften, Weisbaden, 2010., str. 231.-254.

18. Künzel, W., Kommunal Politik in Brandemburg, u: Kost, A.; Wehling, H. G. (ur.), Kommunalpolitik in den deutschen Ländern, VS Verlag für Sozialwissenschaften, Weisbaden, 2010., str. 79.-119.

19. Linder, W., Kommunalpolitik in der Schweiz, u: Voigt, R., Handwörterbuch zur Kommunalpolitik, Studienbucher zur Sozialwissenschaft, VS Verlag zur Sozialwissenschaft, 1984., str. 262.-265.

20. Lorig, W. G., Moderne Kommunalverwaltung in Deutschland, VS Verlag für Sozialwissenschaften, 2014.

21. Lozina, D., Lokalna samouprava - Poredbeno i hrvatsko iskustvo, Pravni fakultet Sveučilišta u Splitu, Split, 2004.

22. Lüth, E., Hamburgs Schicksal lag in ihrer Hand. Geschichte der Bürgerschaft, Marion von Schröder Verlag, Hamburg, 1966., str. 242.-245.

23. Meyer, H., Kommunal Politik in Mecklenburg-Vorpomeranien, u: Kost, A.; Wehling, H. G. (ur.), Kommunalpolitik in den deutschen Ländern, VS Verlag für Sozialwissenschaften, Weisbaden, 2010., str. 187.-204.

24. Oster, R.; Stubenrauch, H., Kommunalpolitik in Rheinland-Pfalz, u: Kost, A.; Wehling, H. G. (ur.), Kommunalpolitik in den deutschen Ländern, VS Verlag für Sozialwissenschaften, Weisbaden, 2010., str. 255.-269.

25. Pelinka, A., Kommunalpolitik in Österreich, u: Voigt, R., Handwörterbuch zur Kommunalpolitik, Studienbucher zur Sozialwissenschaft, VS Verlag zur Sozialwissenschaft, 1984., str. 259.-262.

26. Podoljnjak, R., Gradonačelnik i vijeće, Piprom, Varaždin, 2010.

27. Pusić, E., Lokalna samouprava u Hrvatskoj, Hrvatska javna uprava, vol. 2, br. 2, 2000., str. 347.-349.

28. Rehfeld-Staudt, A.; Rellecke, W., Kommunalpolitik in Freistaat Sachsen, u: Kost, A.; Wehling, H. G. (ur.), Kommunalpolitik in den deutschen Ländern, VS Verlag für Sozialwissenschaften, Weisbaden, 2010., str. 282.-306.

29. Scherer, M., Kommunal Politik in Bremen, u: Kost, A.; Wehling, H. G. (ur.), Kommunalpolitik in den deutschen Ländern, VS Verlag für Sozialwissenschaften, Weisbaden, 2010., str. 120.-147.

30. Wehling, H. G., Kommunal Politik in Baden-Württenberg, u: Kost, A.; Wehling, H. G. (ur.), Kommunalpolitik in den deutschen Ländern, VS Verlag für Sozialwissenschaften, Weisbaden, 2010., str. 21.-39.

31. Wehling, H. G., Kommunalpolitik in der Bundesrepublik Deutschland - Eine Einführung, u: Kost, A.; Wehling, H. G. (ur.), Kommunalpolitik in den deutschen Ländern, VS Verlag für Sozialwissenschaften, Weisbaden, 2010., str. 7.-18.

32. Wohlfarth, J., Kommunalpolitik in Saarland, u: Kost, A.; Wehling, H. G. (ur.), Kommunalpolitik in den deutschen Ländern, VS Verlag für Sozialwissenschaften, Weisbaden, 2010., str. 270.-281.

33. Wollman, H, The directly elected exegutive major in German local government, u: Berg, R.; Rao, N.(ur.), Transforming Local Political Leadership, Palgrave, str. 34.-38. 


\section{PROPISI}

1. Ustav Republike Hrvatske, Narodne novine, broj 56/1990, 135/1997, 8/1998, 113/2000, 124/2000, 28/2001, 41/2001, 55/2001, 76/2010, 85/2010, 5/2014.

2. Zakon o lokalnoj i područnoj (regionalnoj) samoupravi, Narodne novine, broj 33/2001, 60/2001, 129/2005, 109/2007, 125/2008, 36/2009, 36/2009, 150/2011, 144/2012, 19/2013, 137/2015.

3. Zakon o lokalnim izborima, Narodne novine, broj 144/2012.

4. Zakon o izboru općinskih načelnika, gradonačelnika, župana i gradonačelnika Grada Zagreba, Narodne novine, broj 109/2007, 125/2008, 24/2011, 150/2011.

5. Odluka Ustavnog suda Republike Hrvatske od 17. ožujka 2010., broj U-II-38101/2009, Narodne novine, broj 36/2010. 


\section{EXECUTIVE BODIES IN LOCAL SELF-GOVERNMENT - COMPARATIVE EXAMPLES AND CROATIAN EXPERIENCE}

\section{Summary}

This paper aims at analysing the election and jurisdiction of executive bodies in local self-government units, and their relations with the representative bodies, especially in context of mutual influence on local political process. In this context, the models of election of local executive bodies have been analysed and compared with the present German local self-government system, and some other continental European countries. The research has been based on the application of the comparative method. Thus, two models of executive bodies have been established: monocratic and collegial. These models result from implementation of two research methods, i.e. analyses and synthesis. It is expected that the paper will contribute to the better scientific understanding of functioning of executive bodies in local self-government, and dynamics of relations within the triangle including the citizens, executive bodies and representative bodies.

Keywords: $\quad$ Local self-government, political and administrative institutions, executive bodies, types of executive bodies

\section{(c) (1) (s)}

This work is licensed under a Creative Commons

Attribution-NonCommercial 4.0 International License.

* Mirko Klarić, PhD, Associate Professor, Chair of Administrative Science, Faculty of Law, University of Split. Domovinskog rata 8, 21000 Split, Croatia. E-mail address: klaricmirko@gmail.com. ORCID: http://orcid.org/0000-0002-0792-2978. 
